University of Rhode Island

DigitalCommons@URI

Open Access Master's Theses

1992

\title{
Planning and Policy for Household Hazardous Wastes at the Community Level
}

Martha Josten Davey

University of Rhode Island

Follow this and additional works at: https://digitalcommons.uri.edu/theses

\section{Recommended Citation}

Davey, Martha Josten, "Planning and Policy for Household Hazardous Wastes at the Community Level" (1992). Open Access Master's Theses. Paper 731.

https://digitalcommons.uri.edu/theses/731

This Thesis is brought to you for free and open access by DigitalCommons@URI. It has been accepted for inclusion in Open Access Master's Theses by an authorized administrator of DigitalCommons@URI. For more information, please contact digitalcommons-group@uri.edu. 
PLANNING AND POLICY FOR

HOUSEHOLD HAZARDOUS WASTES

AT THE COMMUNITY LEVEL

BY

MARTHA JOSTEN DAVEY

A RESEARCH PROJECT SUBMITTED IN

PARTIAL FULFILLMENT OF THE REQUIREMENTS

FOR THE DEGREE OF

MASTER OF COMMUNITY PLANNING

UNIVERSITY OF RHODE ISLAND

Fall 1992 
MASTER OF COMMUNITY PLANNING

RESEARCH PROJECT

OF

MARTHA JOSTEN DAVEY

Approved:

Major Professor

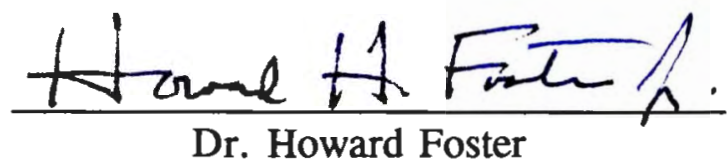

Acknowledged:

Director 


\begin{abstract}
Many household products contain chemicals that are considered hazardous. These products become hazardous waste when discarded, posing potential harm to both human health and the natural environment. With increasing frequency, local governments are being pressured by residents to provide special household hazardous waste management programs. Planners are often the most qualified personnel to construct such programs. At a minimum, planners are requested to assist other staff members or act as the state's liaison to the community. Increasing the planner's knowledge of hazardous waste mitigation is essential to addressing the household hazardous waste problem.

This project analyzes the current household hazardous waste issues faced by many communities. It first defines HHW and documents the causes of, and problems resulting from, present disposal methods, both legal and illegal. Next, it examines municipal liabilities by reviewing legislation and legal decisions, manifesting the need for community action. Finally, policy recommendations are given to help guide planners in devising a strategy to address the household hazardous waste issue in their community. These policy recommendations include education, collection, disposal, community involvement and program evaluation.
\end{abstract}




\section{ACKNOWLEDGEMENTS}

Now that this document is complete, I truly have much to be thankful for and many to thank. Howard Foster, my major professor, showed great enthusiasm for the project and offered just the right amount of criticism. I appreciate his unique sense of humor and hope to continue enjoying it beyond graduation. Mark Motte has been an invaluable source of common sense and style; I find his candor very refreshing. Carole Bell, my outside reader, provided much needed technical assistance and wins the "Quick Turn Around" award for her expedient review. For the occasional, welcome retreats to gardening conversation and fantasy, I thank Suzanne Benson.

In my time spent at CPAD, several colleagues have made a great difference in that they have influenced the way I think. In particular I wish to thank Katia Balassiano, Julie Ross, Nancy Melucci and "Mahk" Dietlin for stimulating conversation, many laughs, and encouragement to constantly seek loftier goals. I am grateful our paths have crossed. Finally, I must recognize the one who has made at least as many sacrifices as I to see this come to fruition. Most importantly, he helped me retain the proper perspective when things became trying. Thanks Shemp. 


\section{TABLE OF CONTENTS}

ABSTRACT $\ldots \ldots \ldots \ldots \ldots \ldots \ldots \ldots \ldots \ldots \ldots$ ii

ACKNOWLEDGEMENTS $\ldots \ldots \ldots \ldots \ldots \ldots \ldots$ iii

TABLE OF CONTENTS $\ldots \ldots \ldots \ldots \ldots \ldots \ldots \ldots$ iv

LIST OF TABLES $\ldots \ldots \ldots \ldots \ldots \ldots \ldots \ldots \ldots \ldots \ldots$

Chapter 1 - INTRODUCTION $\ldots \ldots \ldots \ldots \ldots \ldots \ldots \ldots \ldots$

Chapter 2 - DEFINING HOUSEHOLD HAZARDOUS WASTE $\ldots \ldots \ldots 6$

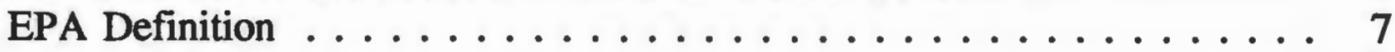

State Definitions . . . . . . . . . . . . . 8

Industry Definition ................... 11

Public Interest Groups . . . . . . . . . . . . . . 12

Conclusion . . . . . . . . . . . . . . . 14

Chapter 3 - DESCRIPTION OF CURRENT EFFORTS . . . . . . . . . . . 16

Collection Methods . . . . . . . . . . . . . . . 17

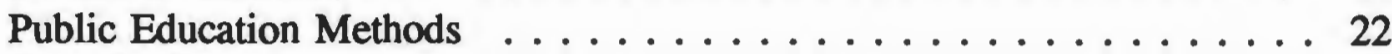

Case Studies . . . . . . . . . . . . . . . . . . 27

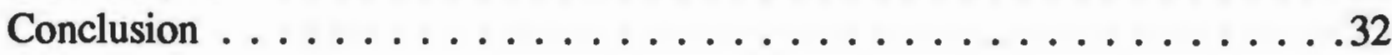

Chapter 4 - LEGAL ISSUES . . . . . . . . . . . . . . . . . 34

Federal Legislation . . . . . . . . . . . . . . 35

State Legislation . . . . . . . . . . . . . . . 37

Potential Liabilities . . . . . . . . . . . . . . . . . . 42

Conclusion . . . . . . . . . . . . . . . 46

Chapter 5 - POLICY RECOMMENDATIONS . . . . . . . . . . . . 48

General Policy . . . . . . . . . . . . . . . . . .49

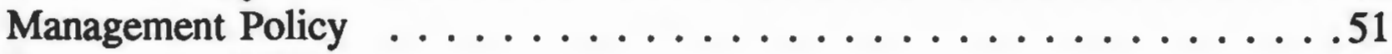

Program Evaluation $\ldots \ldots \ldots \ldots \ldots \ldots \ldots \ldots \ldots \ldots$

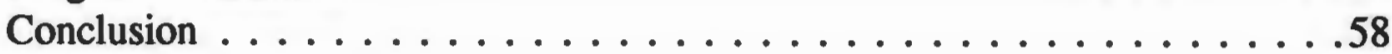

APPENDIX ........................ 60

WORKS CITED . . . . . . . . . . . . . . . . . . . . 69 


\section{LIST OF TABLES}

Table Number

Page

EPA's List of Common Household Hazardous Products . . . . . . . 8 HHW Collection Programs ....................... 18

Permanent HHW Programs $-1991 \ldots . . \ldots 22$ 
Chapter 1

INTRODUCTION 


\section{CHAPTER 1 - INTRODUCTION}

Concerns over the condition of the natural environment are increasing. Even individuals who do not subscribe to a basic doctrine of environmental protection do not deny the seriousness of the present situation, recognizing the need to stem negative health effects. People are learning, firsthand, the consequences of their lifestyles.

One of the increasingly visible environmental problems that people are being forced to confront is disposal of solid waste. This research paper focuses on one small aspect of the larger environmental problem of managing municipal solid wastes. Specifically, it addresses the handling of household hazardous waste at the community level.

During the past few decades, industry has been easily targeted as the major generator of hazardous waste. Industrial processes generate large quantities of wastes that are buried, burned or flushed out to sea. With the advent of recent federal legislation controlling the allowable pollutant output and imposing stiff fines for non-compliance, industry is being held responsible for poor disposal practices. While industry is beginning to be held accountable for its waste products, another group responsible for disposing of toxic substances has escaped accountability. This "group" is comprised of all consumers of motor oil, anti-freeze, pesticides and other hazardous household products. As this group is not necessarily a point-source polluter like industry, it represents a more difficult scenario for control because the pollution may be widespread and nearly impossible to track or predict. (Schwartz 1987)

A major reason for improper disposal of household hazardous waste is that the alternatives for disposal are dwindling. This material is being increasingly prohibited from landfills as problems of groundwater contamination due to this practice become evident 
nationwide. Additionally, the soaring costs of municipal collection day events are reducing their frequency. (Conn 1989)

Conscientious consumers feel trapped by not having a way to dispose of items they were able to purchase without a second thought. Frequently, these households will stockpile hazardous wastes waiting for a collection day event or hoping for the development of some other disposal method. (Duxbury 1990) Some consumers are incensed at being prevented from disposing of hazardous wastes in landfills. These consumers will dispose of the waste on their land, down a house or sewer drain, in a stream, on the side of the road or concealed in other garbage going to the landfill. (Conn 1989)

A case in point involves an EPA study of a shallow aquifer in Florida. The study discovered low to moderate concentrations of synthetic contaminants dispersed over large areas. There were no specific plumes of contamination as found with leaking landfills. A grand jury concluded that "individual and invisible, seemingly minute, acts of contamination such as a single can of paint poured in a single backyard, when multiplied thousands of times over in a community such as ours, in the last analysis pose the greatest threat to our water supply". (Schwartz 1987)

The disposal of HHW down drains or storm sewers could:

- corrode plumbing,

- release harmful fumes,

- create problems in septic systems,

- pollute groundwater, rivers and streams,

- contaminate public water supplies, and

- possibly cause toxic accumulation in food chains.

The incineration of HHW could:

- cause explosions,

- release toxic fumes into the air, and

- concentrate toxic substances in the ash. 


\section{Burial of HHW may:}

- contaminate the soil and groundwater,

- cause fires or explosions, and

- release toxic fumes. (Conn 1989)

Detergents, pesticides, automotive fluids, batteries and solvents constitute just a few of the hazardous products bought off the shelf at any general store. These same products can cause pollution or be toxic, corrosive, ignitable and reactive in the ways described above.

There is also a measurable impact on the physical infrastructure of a community, namely wastewater treatment plants. (Brown 1987) The pollutants in household waste water are mainly cleaning products like toilet bowl and septic tank cleaners, and cosmetics (such as makeup, perfumes, shampoo, etc.). Studies on wastewater treatment and the percentage of HHW in wastewater streams have been conducted. An EPA domestic sewage study reported 19.4 percent of heavy metal and 7.5 percent of organic loadings ending up in publicly owned treatment works. A Seattle Metro Water Quality study stated that residential sources contributed 7 to 11 percent of the heavy metals and 55 to 64 percent of the extractable organics. A sizeable percentage of mercury and arsenic discharged to the two plants were from residential sources.

Most of these hazardous wastes cause serious problems at wastewater plants because they are not designed to remove these wastes. The obvious problem is the corrosive nature of many of the organics. Although there are filtering systems used to extract the organics, they are not 100 percent effective. Many organics end up in the sludge. Heavy metals also end up in the sludge which poses a problem for another aspect of the solid waste picture: composting. Heavy metals in sludge make it undesirable for composting operations designed to produce a benign, usable substance.

As the problem of hazardous waste management grows more extensive, the need for solutions grows more critical. Between diminishing landfill space, drawbacks to incineration, and 
public outrage at ocean dumping, the world is discovering that traditional methods of handling waste are no longer acceptable. The issue becomes even more complex when the waste is hazardous.

This report is organized into five chapters. Chapter 2 states and discusses the various published definitions of household hazardous wastes (HHW) and products. Sources for these definitions include federal and state governments, industry trade associations and community interest groups. Chapter 3 discusses the methods currently in place for addressing HHW collection and education, discussing strategies, documenting costs, and evaluating the effectiveness of such programs. This information was obtained primarily from annual reports on collection activities and through a questionnaire administered to those responsible for HHW disposal at several sites throughout the nation. Legal issues such as the authority of the federal governing agencies and municipal liabilities are addressed in Chapter 4. Finally, policy recommendations given in Chapter 5 are distilled from the information presented in the preceding chapters. 
Chapter 2

DEFINING HOUSEHOLD HAZARDOUS WASTE 


\section{CHAPTER 2 - DEFINING HOUSEHOLD HAZARDOUS WASTE}

The United States Environmental Protection Agency (EPA) has estimated that the average household in this country generates from three to ten gallons of potentially hazardous materials per year. (Ehrich 1992) Given that the 1990 population of the United States is $248,710,000$ (U.S. Bureau of the Census 1992), this amounts to somewhere between 300 million and one billion gallons per year. Which household wastes are considered hazardous varies depending upon which group is defining the term. Household hazardous waste (HHW) has been defined by four groups with high levels of involvement in the issue: the Environmental Protection Agency (EPA), individual states, industry groups and public interest groups.

\section{EPA DEFINITION}

The EPA approach to defining HHW is to combine the federal definitions of hazardous waste and household waste. This definition is developed under the Resource Conservation and Recovery Act (RCRA), the federal law which regulates solid and hazardous waste management. Under the federal regulations, household waste is a solid waste that is discarded or generated from homes and similar dwellings. A household waste is considered hazardous if it is a listed hazardous waste under RCRA, or it exhibits any one of these hazardous characteristics:

- ignitability: easily catches on fire, with a flash point of less than $140^{\circ} \mathrm{F}$.

- corrosivity: easily corrodes material or human tissue; very acidic or alkaline.

- reactivity: explosive, produces toxic gases when mixed with water or acid.

- toxicity: can leach toxic chemicals.

This definition determines what types of household wastes would be regulated as hazardous waste if they were generated in larger quantities, i.e. quantities typically generated from some type of industrial process. Under this definition the EPA has developed a list of broad categories of wastes that can be considered hazardous indicating which characteristics, of the four mentioned above, apply to that type of product. While these types of products are those most 
often considered hazardous, exceptions do exist in each category. Table 1 presents a brief summary of the EPA's categories.

\begin{tabular}{|c|c|c|}
\hline PRODUCT & INGREDIENTS & HAZARDS \\
\hline Household Cleaners & $\begin{array}{l}\text { - sodium hydroxide } \\
\text { - caustic soda } \\
\text { opetroleum distillates } \\
\text { isopropanol }\end{array}$ & $\begin{array}{l}\text { corrosive } \\
\text {-highly ignitable }\end{array}$ \\
\hline Automotive Products & $\begin{array}{l}\text { organic solvents } \\
\text { petroleum distillates }\end{array}$ & $\begin{array}{l}\text {-highly ignitable } \\
\text {-emit toxic fumes }\end{array}$ \\
\hline $\begin{array}{l}\text { Home Maintenance/ } \\
\text { Improvement Products }\end{array}$ & ๑organic solvents & $\begin{array}{l}\text {-highly ignitable } \\
\text {-emit toxic fumes }\end{array}$ \\
\hline $\begin{array}{l}\text { Lawn and Garden } \\
\text { Products }\end{array}$ & $\begin{array}{l}\text { arsenic } \\
\text { diazinon } \\
\text { chlordane }\end{array}$ & $\begin{array}{l}\text { - corrosive } \\
\text {-highly ignitable } \\
\text { emit toxic fumes } \\
\text { carcinogenic }\end{array}$ \\
\hline
\end{tabular}

The EPA believes that most household products are safe if used properly and safely stored. The agency surmises that research should focus on the fate and effects of these products when disposed of in various ways. (Maples 1987)

\section{STATE DEFINITIONS}

Several states have developed legal definitions as part of an overall waste handling program. The following presents the definitions of only a few of these states. IOWA

The Iowa definition reads: Household hazardous material means a product used for residential purposes and designated by rule of the Department of Natural Resources and may include hazardous substances, as defined, and hazardous waste, as defined, and shall include but is not limited to: 
- motor oils

- gasoline/diesel additives

- fertilizers (petro. base)

- paints (except latex)

- caustic household cleaners

- stain removers (petro. base)
- motor oil filters

- degreasers

- polishes

- solvents

- thinners

- waxes/lacquers

Evident for the first time in the Iowa definition was the list of household products which are excluded from being considered hazardous: laundry detergents or soaps, dishwashing compounds, chlorine bleach, personal care products and soaps, cosmetics and medications. (Iowa 1987) These items were omitted as a result of lobbyist's efforts. (Krogulski 1992) This delivers an inconsistent message given that many of these products present hazards equivalent to other products not excluded. This concept of excluding personal use products was later implemented by other states.

\section{MINNESOTA}

The Minnesota definition states that "Household hazardous waste means waste generated from household activity that exhibits the characteristics of, or that is listed as, hazardous waste under agency [Minnesota Pollution Control Agency] rules but does not include waste from commercial activities that is generated, stored, or present in a household." (Minnesota 1989) Excluding waste that may be generated from a home business, or transported to a home from a business, is only acceptable here if it is addressed in another state statute.

\section{NEW HAMPSHIRE}

In House Bill 776-FN, not yet passed by the New Hampshire legislature, both "household hazardous material" and "household hazardous waste" are defined. Household hazardous material is defined as a product used for residential purposes and containing materials designated as hazardous waste by rules adopted by the Division of Waste Management under two separate state regulations. The list of household hazardous materials is almost identical to the Iowa list, 
including the exceptions. Household hazardous waste "means the remaining residue of household hazardous materials in containers which contained such materials, or the remaining ingredients, in whatever form, of household hazardous materials as defined".

\section{VERMONT}

Vermont does not legally define HHW, but instead provides a list of household hazardous products. (Vermont 1991) Products listed are:

- all motor oil products including, but not limited to, oil, engine lubricants, and transmission fluid and additives;

- all types of gas treatments and gas line freeze-up products;

- engine cleaners and solvents;

- shoe polishes, floor waxes, car waxes, furniture polishes, spray dust cleaners, furniture stains;

- mineral spirits, turpentine, alcohols not for human consumption, cresol, naphtha;

- paints, whether for brush or spray, aerosol paints, lacquers and thinners (except water);

- drain cleaners, toilet bowl cleaners, oven cleaners;

- spot and stain removers with petroleum base;

- fertilizers with petroleum base;

- pesticides falling within the state definition;

- lead-acid batteries, pool chemicals, photographic chemicals, antifreeze, wood preservatives, windshield wiper solution, most glues and adhesives, self-lighting charcoal, charcoal lighter, butane lighters, all aerosols (except personal care products).

\section{WASHINGTON}

The definition reads: "Household hazardous substance means any liquid, solid, contained gas or sludge, including any material, substance or product, commodity or waste, used or generated in the household, regardless of quantity, that exhibits any of the characteristics or 
criteria of "dangerous waste" as set forth in Chapter 273-303 of the Annotated Code. Such substances become moderate risk waste when discarded." (Maples 1987)

The Washington State HHW statute requires that local hazardous waste planning guidelines be set up. The guidelines suggest that local planning efforts use chemical ingredients of individual products as a basis for discriminating between hazardous and non-hazardous products. A list is also provided with the common constituents contained in those products. A revised list is found in Appendix A. Washington has created seven broad categories of potentially hazardous household products:

- auto, boat and equipment maintenance products,

- home and household maintenance,

- paint products,

- repair and remodelling,

- hobby, pet and recreation materials,

- personal care products,

- pesticides and herbicides.

\section{INDUSTRY DEFINITION}

The Chemical Specialties Manufacturers Association (CSMA) definition of HHW is:

A discarded material, product or mixture that reaches groundwater from solid waste landfills or improper disposal, or reaches surface water from disposal in sewer systems or septic systems, IN SUFFICIENT QUANTITIES to create, by itself or in conjunction with other materials, a verifiable level of toxicity that could affect human health or the environment. (Maples 1987)

The CSMA agrees that certain household materials should be segregated from the general waste stream. It is evident, however, that they have a narrow view of the materials this includes: the potential hazards of chemicals contained in common household products is almost completely ignored. They believe that the materials that should be segregated are easily distinguishable from normal household consumer products, such as:

- certain pesticides that have been scientifically determined to persist in the environment, such as DDT;

- extremely toxic materials that pose a human health hazard, such as arsenic or strychnine; 
- used motor oil and gasoline which can be recycled and refined;

- ammunition and explosives;

- unidentified material of a suspicious nature.

The National Paint and Coatings Association (NPCA), in an April 1987 HHW Policy statement, generally supported the federal definition of HHW as put forth by the EPA. The following points were made by the NPCA in its statement:

- Only small quantities of hazardous waste are disposed of in municipal landfills.

- Most products are hazardous only in large bulk quantities.

- The small amount of hazardous material is absorbed by solid waste.

- More scientific evidence is needed.

NPCA addressed the issue from the perspective that there is insufficient scientific evidence to conclude that the disposal of household chemical products, including paints, in municipal landfills, creates an adverse impact on the environment. NPCA believes that the extent of environmental and health hazards posed by the disposal of household chemical products and their waste streams in municipal landfills is not fully determined.

\section{PUBLIC INTEREST GROUPS}

A number of organizations have attempted to define HHW by listing items considered hazardous. These efforts are most commonly done at the local level when community groups and organizations decide to organize a collection program. These lists vary widely, but usually major categories are assembled similar to EPA or the states.

The National Audubon Society's (NAS) position is that a product should be considered to be hazardous if it exhibits any characteristics which are:
- toxic
- ignitable
- reactive
- infectious
- corrosive
- radioactive 
They have developed a list, as have many other groups, which includes: pesticides, herbicides, paint products and preservatives, cleaners, and automotive wastes or products. (Maples 1987)

The Clean Water Fund, a non-profit research and education organization whose work complements the grass-roots citizen group Clean Water Action in Rhode Island, publishes a chart of household alternatives. (Clean Water Fund 1989) The chart does not offer a definition of HHW but does identify twenty categories or specific items, stating the problem with the item and what the solution is. Items listed are:

- floor/furniture polish

- all-purpose cleaners

- auto. dishwashing products

- automotive products

- deodorizers

- dishwashing liquids

- disinfectants

- disposables

- drain cleaners

- flea/tick control
- aerosols

- glass cleaner

- pesticides

- laundry products

- metal polishes

- mold/mildew cleaners

- mothballs

- oven cleaners

- paints/paint thinner

- toilet cleaners

Unique to this list is the inclusion of disposables such as plastics, styrofoam and diapers. The problem stated is that landfills are being filled with these non-biodegradable products; there is no mention of an imminent hazard such as that presented to groundwater by various chemicals. While disposables do represent a solid waste problem, they do not meet EPA's criteria for HHW and it is misleading to include them on this list.

The League of Conservation Voters, an independent, non-partisan organization in New England dedicated to electing environmental leaders to Congress also publishes an informational sheet on HHW. (League of Conservation Voters) They do not define HHW but offer examples of common products, most of which have been previously listed. A few specific products not seen on the other lists include pest strips and air fresheners. This publication also offers alternatives. 


\section{CONCLUSION}

The federal definition of household hazardous waste was developed by the EPA under the Resource Conservation and Recovery Act, which regulates all solid and hazardous waste management. A household waste is considered hazardous if it is ignitable, corrosive, reactive and/or toxic. The EPA believes that more research is needed to better define the problem of household hazardous waste disposal.

Many states have taken the EPA definition one step further and listed the types of products included, such as automotive fluids, paint products, chemical garden products and household cleaners and polishes. This approach informs the consumer of the diversity and extensiveness of household products that may be problematic when disposed of. Other products, such as medicines, cosmetics, chlorine bleach and laundry products, meet one or more of the four criteria set forth by the EPA, but are specifically excluded from some state definitions without explanation. This approach seems inconsistent given that many of these products exhibit the four characteristics outlined by the EPA.

Public interest groups reviewed and expanded both the EPA and state definitions. The National Audubon Society added "infectious" and "radioactive" to the list of four hazardous characteristics identified by the EPA. While these types of wastes certainly are hazardous, they do not display one of the four characteristics of a hazardous material as defined by the EPA. Additionally, the volume of this waste is presumed to be negligible in comparison to the waste generated from household products. The Clean Water Fund added disposables to the lists generated by the states, clouding the issue by going beyond the intended definition of "hazardous" as put forth by federal and state legislation.

The industry groups reviewed, not surprisingly, took the most restrained view of household hazardous waste in their definitions. An association of chemical manufacturers published a 
definition which included several elements not found in any other definition. It states that quantities sufficient to cause a level of toxicity high enough to effect human health, or the environment, must reach ground or surface water when discarded. This is presumably a very complex condition to measure given the number of variables to consider. Once it was determined that a "high enough" toxicity level had been reached, some damage will already have been done. Remedial action is costly. The National Paint and Coatings Association agreed with the EPA on the need for more research. They believe that since household hazardous waste is disposed of in such small amounts, and absorbed by other solid waste present, in effect its level of "hazardousness" is questionable. While there is no argument regarding the need for more research, this view ignores the potential of the hazard increasing due to uncontrolled mixing of incompatible chemicals. Until more research is conducted, a conservative approach offers the greatest safety reassurances. 
Chapter 3

DESCRIPTION OF CURRENT EFFORTS 


\section{CHAPTER 3 - DESCRIPTION OF CURRENT EFFORTS}

There are currently two overall strategies for addressing the HHW issue in the United States: collection and education. Collection of HHW is intended to separate this waste from the general A solid waste stream in order to prevent it from entering a municipal landfill where it may eventually contaminate groundwater. The waste collected is either incinerated, disposed of in an approved hazardous waste landfill or "recycled." Public education efforts are aimed at compelling consumers to recognize the constituents of the products they purchase, to understand their potential dangers and the need for proper disposal and, ideally, to alter their buying habits. All collection strategies reviewed include some element of public education. This chapter takes a comprehensive look at these and other public education efforts as well as how collection is conducted in the United States and Europe.

\section{COLLECTION METHODS}

Household hazardous waste collection has been in place in many states for over a decade. Collection of HHW primarily exists in two forms: temporary collection events and permanent collection facilities. The number of both collection activities and the number of states participating has continued to increase over time. California has led the nation in total number of collection events, perhaps due to their extreme drought conditions. Table 2 lists the number of collection programs, both permanent facilities and collection events, by state, for the past eleven years. Each state has had at least one HHW collection activity within this time frame: 1991 was the first year that all 50 states reported some type of collection activity. After the only decline in the number of programs (between 1990 and 1991), there is a drastic jump in the total number of programs in 1991. 


\begin{tabular}{|c|c|c|c|c|c|c|c|c|}
\hline STATE & $\begin{array}{l}1980- \\
1985\end{array}$ & 1986 & 1987 & 1988 & 1989 & 1990 & 1991 & TOTAL \\
\hline Alabama & 1 & 0 & 0 & 0 & 1 & 2 & 2 & 6 \\
\hline Alaska & 9 & 7 & 2 & 6 & 10 & 9 & 15 & 58 \\
\hline Arizona & 0 & 0 & 1 & 1 & 2 & 2 & 4 & 10 \\
\hline Arkansas & 0 & 0 & 1 & 0 & 0 & 0 & 1 & 2 \\
\hline California & 55 & 28 & 81 & 99 & 114 & 181 & 148 & 706 \\
\hline Colorado & 5 & 0 & 0 & 0 & 3 & 3 & 3 & 14 \\
\hline Connecticut & 10 & 25 & 24 & 38 & 37 & 49 & 41 & 224 \\
\hline Delaware & 0 & 0 & 1 & 0 & 0 & 1 & 2 & 4 \\
\hline Florida & 43 & 16 & 13 & 18 & 72 & 85 & 94 & 341 \\
\hline Georgia & 0 & 0 & 0 & 0 & 0 & 0 & 2 & 2 \\
\hline Hawaii & 0 & 1 & 1 & 2 & 9 & 0 & 1 & 14 \\
\hline ldaho & 0 & 0 & 0 & 0 & 2 & 3 & 2 & 7 \\
\hline lllinois & 0 & 0 & 1 & 6 & 1 & 10 & 11 & 29 \\
\hline Indiana & 2 & 1 & 2 & 5 & 4 & 10 & 3 & 27 \\
\hline lowa & 0 & 2 & 0 & 3 & 12 & 6 & 9 & 32 \\
\hline Kansas & 0 & 3 & 0 & 0 & 0 & 16 & 13 & 32 \\
\hline Kentucky & 3 & 0 & 0 & 0 & 0 & 4 & 4 & 11 \\
\hline Louisiana & 1 & 1 & 1 & 2 & 2 & 2 & 2 & 11 \\
\hline Maine & 3 & 1 & 0 & 1 & 3 & 6 & 2 & 16 \\
\hline Maryland & 1 & 0 & 2 & 3 & 5 & 10 & 5 & 26 \\
\hline Massachusetts & 78 & 78 & 51 & 101 & 102 & 78 & 63 & 551 \\
\hline Michigan & 10 & 14 & 11 & 23 & 30 & 52 & 60 & 200 \\
\hline Minnesota & 7 & 10 & 9 & 33 & 56 & 31 & 42 & 188 \\
\hline Mississippi & 0 & 0 & 0 & 0 & 0 & 0 & 1 & 1 \\
\hline Missouri & 0 & 0 & 0 & 2 & 1 & 5 & 0 & 8 \\
\hline Montana & 1 & 0 & 0 & 0 & 0 & 0 & 0 & 1 \\
\hline Nebraska & 3 & 0 & 1 & 3 & 3 & 6 & 1 & 17 \\
\hline
\end{tabular}




\begin{tabular}{|c|c|c|c|c|c|c|c|c|}
\hline STATE & $\begin{array}{l}1980 \\
1985\end{array}$ & 1986 & 1987 & 1988 & 1989 & 1990 & 1991 & TOTAL \\
\hline Nevada & 0 & 0 & 0 & 0 & 0 & 0 & 2 & 2 \\
\hline New Hampshire & 5 & 11 & 22 & 19 & 27 & 23 & 19 & 126 \\
\hline New Jersey & 8 & 7 & 3 & 13 & 33 & 39 & 47 & 150 \\
\hline New Mexico & 1 & 0 & 0 & 0 & 3 & 2 & 3 & 9 \\
\hline New York & 15 & 21 & 28 & 44 & 62 & 73 & 56 & 299 \\
\hline North Carolina & 2 & 0 & 0 & 0 & 5 & 6 & 6 & 19 \\
\hline North Dakota & 2 & 0 & 0 & 1 & 1 & 1 & 0 & 5 \\
\hline Ohio & 2 & 1 & 0 & 1 & 2 & 4 & 7 & 17 \\
\hline Oklahoma & 0 & 0 & 0 & 0 & 1 & & 7 & 9 \\
\hline Oregon & 3 & 2 & 2 & 3 & 3 & 6 & 11 & 30 \\
\hline Pennsylvania & 1 & 1 & 2 & 5 & 6 & 3 & 4 & 22 \\
\hline Rhode Island & 9 & 4 & 7 & 5 & 5 & 5 & 2 & 37 \\
\hline South Carolina & 0 & 0 & 0 & 1 & 0 & 3 & 1 & 5 \\
\hline South Dakota & 0 & 1 & 0 & 0 & 0 & 0 & 1 & 2 \\
\hline Tennessee & 0 & 1 & 0 & 0 & 0 & 1 & 0 & 2 \\
\hline Texas & 0 & 6 & 2 & 5 & 3 & 11 & 6 & 33 \\
\hline Utah & 0 & 2 & 0 & 0 & 1 & 2 & 6 & 11 \\
\hline Vermont & 3 & 5 & 3 & 2 & 6 & 14 & 7 & 40 \\
\hline Virginia & 1 & 3 & 7 & 15 & 10 & 13 & 12 & 61 \\
\hline Washington & 21 & 12 & 12 & 17 & 37 & 63 & 55 & 217 \\
\hline West Virginia & 1 & 0 & 1 & 0 & 0 & 1 & 1 & 4 \\
\hline Wisconsin & 8 & 9 & 9 & 7 & 18 & 16 & 16 & 83 \\
\hline Wyoming & 0 & 0 & 0 & 0 & 1 & 1 & 2 & 4 \\
\hline TOTAL/YEAR & 315 & 273 & 300 & 484 & 693 & 859 & 802 & 3725 \\
\hline TOTAL STATES & 25 & 28 & 28 & 31 & 38 & 43 & 46 & 50 \\
\hline
\end{tabular}




\section{COLLECTION EVENTS}

Collection events in the U.S. are usually one day opportunities at one or more sites throughout the area over which the organizer has "jurisdiction". For example, a county government sponsoring the collection may have several locations for drop-off, especially in the larger counties found in the western states. A New England town, on the other hand, is likely to have a single location for its residents only.

Reported costs per participant for collection events vary widely as there is no standard reporting format. Some cost figures include all costs, direct and indirect, while others are for waste contractors only. Without the benefit of knowing what factors were included, legitimate cost comparisons between collection events are unlikely. Case studies in a following section provide more information on costs.

The reported volume of waste collected per participant also varies widely between events. This is primarily due to differences in waste packaging. Some events measure amounts collected by the number of 55-gallon drums, some of which are lab-packed and some of which are bulked. Others report gallons or pounds of waste collected.

In an attempt to reduce the volume of waste being handled, and subsequently the cost of disposal, many event coordinators have instituted recycling programs. These programs are commonly referred to as "drop and swap"; participants are asked to put only usable items, such as paint in good condition and unused cleaning products or pesticides, in a specific area for others to retrieve for their own use. Paint is consistently the most prevalent material and often goes to charitable groups. "Drop and swaps" are growing in popularity as they allow a municipality to lessen costs through reduced volumes of wastes requiring disposal. There are no known liability problems associated with this practice. 
Although comparisons of individual collection event reports are difficult, surveys have been conducted in an attempt to quantify the waste collected and determine the most common collection activities. One such survey questioned persons identified as having involvement with HHW collection drives throughout the nation. (Environmental Project Group 1990)

A summary of their published report presents the following findings:

- the majority of HHW collection drives were sponsored by a governmental agency for one day, at one site, once a year, to serve an area that crosses municipal and/or county lines;

- hazardous waste disposal contractors were selected by competitive bidding and usually assumed legal liability;

- there is no statistical correlation between the population of the collection area and either the total cost of the HHW collection drive or the cost per barrel to dispose of the waste;

- the majority of HHW collection drives were funded from one ongoing source, commonly general state taxes, general local taxes, local user fees or a combination of these and other sources;

- the majority of HHW collection drives recycled materials collected, or permitted participants to swap materials;

- recycling did not significantly reduce the cost of the collection drives (although it was noted that the material removed through the "drop and swap" practice certainly saved money.)

The median population of the collection area was 237,000 persons with a mean of 336,000 . Median and mean costs per collection drive were $\$ 49,000$ and $\$ 116,000$, respectively, while cost per barrel of waste material was $\$ 350$ and $\$ 423$, respectively.

\section{PERMANENT PROGRAMS}

Sixteen of the 50 states have a total of 96 permanent household hazardous waste collection facilities. (Duxbury 1991.) The states with permanent facilities are listed in Table 3, representing diverse population densities and levels of urbanization. It may surprise some to see permanent HHW facilities in the states of Kansas and Nebraska which have a relatively low population density, however, "agricultural" states usually include farm pesticides in their HHW 
collection. The individual policies of these permanent facilities concerning types of wastes accepted, recycling options and hours or days of operation vary greatly between states as well as within each state with multiple facilities.

Comparing the number of total collection events in Table 2 with the number of permanent facilities listed in Table 3, it becomes apparent that all 16 states that have permanent facilities also

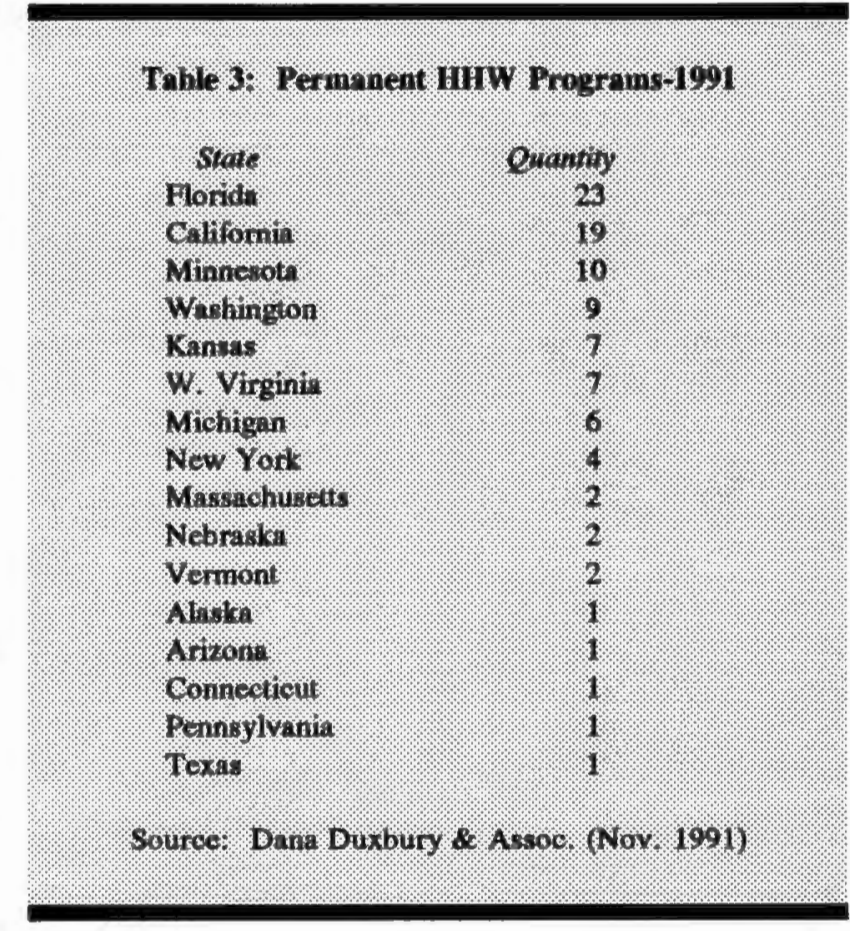
conduct periodic collection events. This illustrates the effort of these states to make collection activities convenient and accessible.

\section{PUBLIC EDUCATION METHODS}

The need for public education is the most widely agreed upon aspect of the HHW issue. A questionnaire on HHW labeling legislation drew a clamor for the need for education. (Davey 1991) The majority of the questionnaires returned had written in an opinion or strategy regarding educational efforts. These respondents promote programs in schools, public service announcements on the television and radio, and dedicated newspaper columns.

\section{COLLECTION SITE EDUCATION}

All collection programs include some element of education for participants. Collection events and permanent facilities open on a limited schedule usually publicize via public service announcements for up to two weeks prior to the event or the open hours. Participants are frequently asked to respond to a survey to help quantify and identify the waste, and often to aid 
the organizers in improving service. Materials explaining the HHW issue are usually handed out. The effectiveness of this type of educational approach is marginal. It is presumed that little is gained by trying to educate someone already participating in the program.

In Monroe County, Indiana, residents who utilize the permanent facility receive free brochures offering a weekly scheduled course or special presentations for schools or organizations on how to make safe alternative cleaners from innocuous ingredients. Containers and labels are provided for the workshops. (St. John 1992)

\section{LABELING LEGISLATION}

Household hazardous product labeling legislation, as a form of education, is currently considered to take three possible forms: labeling of the products themselves, labeling of the shelf the products are sold from at the marketplace, or affixing a tax stamp to the product.

A questionnaire was mailed to individuals responsible, in some way, for HHW disposal in their state. (Davey 1991) A total of 75 were mailed to 49 states and Washington, D.C. (Rhode Island was omitted as it was the state of origin of the questionnaire.) Thirty-nine responses were received from 36 states. Of the potential types of labeling legislation, only shelf-labeling is actually in existence for some states. This legislation is discussed briefly below and is presented in more detail in the following chapter.

Product Labeling

Product labeling received the greatest endorsement from the respondents. There was no preconceived definition of this term when selected for the questionnaire. As was evident from the responses, product labeling is thought of in two ways: executed by either the retailer or the manufacturer.

The preferred method was federally mandated, standardized labeling requirements for the manufacturer. There were several reasons for this choice: 
- it places the burden of compliance on the "creator" of the product; the one profiting most from the product,

- the cost is passed on to the consumer, the "generator" of the HHW,

- it is consistent with what is currently in place for medicine and food labels,

- the cost for state by state implementation of labeling standards is prohibitive,

- it is not reasonable to expect a manufacturer to comply with different rules for each state, and

- it is a one time effort and cost for the manufacturer to change the product label, but a continuous effort and cost for the retailer to affix labels to the products.

In general, product labeling was preferred by the respondents because the disposal information is product specific, permanent and travels with the item. Many felt that consumers may not take the time to read information on display at the store, as with shelf labeling, or that it may be forgotten soon after their departure. Additionally, it is speculated that retailers will be resistant to the extra work involved and the potential loss of sales brought on by a prominent store display.

\section{Shelf Labeling}

Shelf labeling was the most widely agreed upon term. The accepted concept of shelf labeling includes an eye-catching symbol attached to shelves holding household hazardous products, usually next to pricing information. In addition, informational booklets are displayed nearby and are available for consumers to take, or often the retailer is responsible for giving purchasers of HHW a booklet, provided by the state, at the checkout counter.

The primary reason this method was chosen was its ease of implementation. Once the materials are provided to the retailer the shelf labels can be affixed and the consumer information displayed. The only remaining work for the retailer is the simple task of ensuring there are a sufficient number of booklets available to consumers on a continuing basis. 
Another argument for this method was that the consumer is reminded of the issue every time they go to the store. Many respondents feel that the majority of consumers do not read the product labels, but feel that their attention will be gained by an eye-catching symbol.

One drawback to this method is that there is a continuous expenditure of state monies for printing consumer information yet the program does not generate any revenue. Additionally, considering the spatial distribution of retailers in rural areas, or the high quantities of retailers in densely populated areas, enforcement may be difficult.

\section{Tax Stamp}

Like product labeling, the tax stamp method was thought of on both the federal and state levels; neither level was favored over the other. The main reason given by the supporters of this method was the concept of charging consumers with the "privilege" of using a Household Hazardous Material (HHM), and making sure they know they are being charged for that privilege. This hopes to accomplish three things: it makes the consumer learn why they are being charged extra, it encourages them to look for less expensive alternatives or to use that product more conservatively, and it raises revenues for HHW programs. Supporters feel that economic forces, especially given today's weakened economy and high jobless rate, speak to a larger cross-section of consumers than do environmental or health considerations. The few detractors of this method argued that there are enough consumer taxes already, and another will only serve to irritate the public.

A minority of respondents said that this issue was not a concern to their state, so legislation was not required at this time. They chose not to select a hypothetical method because they were unfamiliar with them. 


\section{SCHOOL AGE EDUCATION}

Vermont is one of the few states that collects household batteries. Landfill disposal of Nickel-cadmium (Ni-Cad) batteries (and paint) is prohibited in regions where there are regular HHW collections. Five elementary schools participated in a Central Vermont Regional Planning Commission sponsored household battery collection program. Over 2500 batteries were collected by 1000 students. The students at the winning school were awarded free ice cream from Jerry of Ben \& Jerry's ice cream. (Cohen 1992)

Puppet shows are another method of educating school-age children. In Thurston County, in the state of Washington, a puppet show about beneficial insects and the need to reduce pesticides is performed for grades K-3 as part of their overall HHW education program. (Toteff 1992) In Nevada County, California, puppet shows for all ages about hazardous materials and their proper disposal are performed twice daily at the Nevada County Fair. Also in California, the town of Chula Vista has received state funds for an education project for schools to be prepared in English and Spanish. (Purin 1992)

\section{OTHER EDUCATION EFFORTS}

The Tennessee Valley Authority (TVA) coordinated "A Clean Environment Begins at Home" campaign for its employees during Earth week. (Kiraly 1992) Information packages were mailed to 19,000 employees while other educational materials were distributed at fairs and TVA facilities. One hundred copies of California's League of Women Voters video, Cleaning up Toxics at Home, were purchased and shown in conjunction with collection at three sites. A follow-up survey on the effectiveness of this educational approach showed an increase in awareness on the issue.

Coordinated by the Washington Department of Ecology is a stenciling campaign wherein Scouts and other youth groups spray paint storm drains with the message "Dump No Waste - 
Drains to Stream" with a logo of a trout. This is intended to alert people that anything they discard into the drains does not go to a sewage treatment plant, but to the nearest stream, lake or ocean. (Cline 1989) This practice is becoming common in other parts of the U.S. as well.

\section{CASE STUDIES}

Several case studies of current programs in the U.S. and Europe are presented below. These examples provide insight to some of the variety found in collection strategies.

\section{SOUTH DAKOTA}

South Dakota conducted a Pilot Program to collect and dispose of hazardous waste from residences, schools, small businesses and farms at a local landfill. This was to be in accordance with the Toxic Cleanup Day section of the Governor's 1989 Centennial Environmental Protection Act. Money was not appropriated until the following legislative session when $\$ 100,000$ was authorized from the Groundwater Protection Fund for the collection held in May of 1991. (South Dakota 1992)

The collection was scheduled to be held for an eight hour period. Due to overwhelming participation, the project cost was estimated to be at or near the budgeted amount a mere two hours after it began. Approximately 118 individuals dropped off toxic and hazardous wastes; over 200 vehicles were turned away. Recyclable wastes such as oil, antifreeze or batteries were collected for the duration of the scheduled time. The costs for collection, identification, sampling, analysis, packaging and disposal or recycling of the wastes was approximately eight dollars per pound.

Participants were asked to fill out and return a postcard survey; there was a 40 percent response. A summary of the results indicate that 85 percent are willing to pay for a collection activity, (52 percent would pay up to $\$ 10$ and 28 percent up to $\$ 20$ ), 41 percent appreciate the 
opportunity to be rid of wastes stored for a long period (up to 20 years!) and 93 percent believe the program should continue.

A brief summary of some of the observations from the State's Department of Environment and Natural Resources include:

- The majority of wastes received were very old and in no condition to be used or recycled. It is apparent that storage of these materials was preferred to landfill disposal by the owners implying that there is an awareness of the environmental hazards associated with landfill disposal. It also appears that the initial collection project will require more resources and be more costly than an ongoing program in which the increased frequency of collection will keep the wastes in a newer, more usable condition thus increasing the opportunity for recycling.

- The success of the program is dependent upon the support and coordination of volunteers at the local level. Understanding the attitudes and the level of awareness within the community where the collection is to take place is very important to the success of the collection day.

- Advertising is very important in order to inform the public of the dates, times and places of the collection and also to inform the public of the types of wastes accepted during the collection. A continuing educational program to provide information to the public regarding alternatives to the use of toxics in their homes may greatly reduce the amount of wastes generated.

\section{IOWA}

Iowa's Department of Natural Resources (DNR) sponsors "Toxic Cleanup Days" which are generally one-day events in varying counties throughout the state. (lowa 1992) Most of the hazardous wastes are transported out of state for disposal at EPA approved facilities; used oil, lead-acid batteries and usable paint are recycled locally. Due to dramatic increases in participation and program costs in 1989 , the program was restructured to provide more efficient and effective service to citizens.

The program was changed in two significant ways. First, the program was revised to require counties hosting a collection event to provide a task force to establish an agenda for proper HHW management on an ongoing basis. Local communities were requested to:

- establish household hazardous materials information in local libraries; 
- institute annual school education programs on household hazardous materials;

- provide ongoing education to the public;

- assist retailers with the display of consumer education materials as mandated by state law;

- provide local sources for assistance with proper household hazardous material management.

The second change in the program was to conduct collection events by appointment only, with a two week period preceding the event during which people called to schedule appointments. Iowa is the first state in the nation to sponsor a Toxic Cleanup Day by appointment. Advantages of the "appointment-only" event proved to be numerous:

- advertising a local number to call for an appointment enhances awareness of a local source for future HHW management assistance;

- training volunteers to staff phones and help people with proper HHW management results in a local base of people who are very knowledgeable about HHW management;

- citizens who call receive personal assistance in learning how to manage their waste properly (by using up or diverting many products) in contrast to events held without appointments where they would bring in all waste products from the home, some toxic and some not, as this was seen as a "quick fix" solution;

- service time is reduced to three to five minutes per participant;

- for every participant who schedules an appointment, one or more is able to receive instructions on proper management and does not have to make an appointment, thus eliminating unnecessary costs;

- a more accurate estimation of the costs of the event can be anticipated with scheduled participants and lists of wastes they intend to bring.

In 1991, funding was provided by legislation to start establishing regional permanent siting. Permanent sites are expected to provide a better, more cost effective mechanism for the collection of HHW that must be disposed of through a hazardous waste contractor. 


\section{FLORIDA}

The Florida Solid Waste Authority (SWA) in Palm Beach County has a comprehensive program to manage HHW in place. (Florida 1992) The program consists of a county disposal complex which receives HHW and is fed by satellite transfer stations. The permanent facilities were prompted by results of surveys conducted during collection events. The state utilizes collection events primarily to publicize the opening of new satellite stations.

The main facility consists of a 2500 square foot building that houses offices, a laboratory and a packaging-receiving area. Additionally, four prefabricated buildings house the wastes temporarily to enable more efficient packaging. Substantial time and disposal cost savings have been realized by developing bulked waste streams. Over the past year, citizen participation increased by 30 percent but the number of drums disposed of remained constant. All hazardous waste collected is shipped off site for disposal at EPA regulated facilities. Products in their original containers, and in good condition, are stored for later reuse and public distribution. This facility also accepts waste from commercial businesses, or "conditionally exempt small quantity generators", as defined by the EPA.

\section{ENGLAND}

In the town of Leeds, a WasteWagon - a purpose-designed vehicle that roams the town, collecting HHW - is a pilot program introduced by the city council in March of 1992. (Wheal 1992) The wagon will primarily pick up a range of paints and solvents, garden chemicals and automotive products. The service is available to an estimated 90,000 households. (Kerrell 1992)

The vehicle has been well equipped for its task. There is a reception hatch for receiving the waste, measuring and weighing equipment, a sink with running water, a public address system and separate storage areas for various types of waste. There is a fire extinguisher, a portable 
shower and eye irrigator, and a telephone. The cost to modify the vehicle to this condition is unknown.

Key to this scheme is support from industry: industrial participants in the project readily admit that they are involved as manufacturers and sellers of the hazardous items. Two of the companies involved, a producer of machine and domestic oils and a producer of paints, have already begun extensive recycling programs, including the recycling of product containers.

The highest volume of waste expected to be collected, as is true in the U.S., is paint. The council plans to conduct paint give-aways with the leftover paint being channeled to companies that can reblend it. The vehicle only accepts wastes that have clear recycling or disposal paths. Medicines are rejected as they can be returned to the pharmacist.

\section{DENMARK}

A regulation went into effect in January of 1991 mandating that 275 Danish municipalities collect HHW. (Johansson 1991) Although the government mandated collection, the municipalities may create their own programs.

Some cities have arranged with paint shops to accept household paints and solvents in exchange for a token payment from the city. The shops act only as the collection point: municipalities are then responsible for disposal. The major advantage of this is that paint shops are numerous and therefore convenient to the general population. Additionally, the staff in the shop can assist the town in how best to handle the waste. Unfortunately, the shops limit what they will accept and receive insufficient economic incentive for their efforts.

Another method has been to place manned mobile containers in neighborhoods or near shops once or twice annually. This method was later improved upon by the introduction of a special collection van. The van takes a fixed route up to a dozen times per year where it stops every 100 
to 200 yards and rings a bell to alert homeowners of its arrival. This provides the greatest convenience to the public, but they must be prepared for the brief stop.

Finally, the highest level of service is offered by a few municipalities that provide households with a special hazardous waste plastic box, approximately two cubic feet in volume with sorting instructions. The boxes are child-proof and must be put out in advance of collection which occurs on fixed dates at least twice per year, and sometimes monthly.

\section{CONCLUSION}

All fifty states, and many European countries, have conducted some type of collection activity for household hazardous wastes. Although education is a critical part of the overall strategy regarding $\mathrm{HHW}$, it is doubtful that it will be successful at reducing the volume of waste to the point that eliminates the need for collection. Given the increased awareness in environmental matters this decade, the demand for such programs is on the rise. Unfortunately, the financial resources necessary to conduct collections frequently are insufficient.

There is great variation and recent innovation in collection activities. This is necessary to address the variables involved in devising a program. The type and frequency of collection activities selected for an area is influenced not only by fiscal matters, but also by personnel resources, population density, and inclusion of businesses and farms and disposal options, among other things. Problems encountered are often overcome through collaboration with another town or county.

Public education efforts are becoming more creative as well. Originally limited to public service announcements, new efforts include targeting both government workers and students. Both of these groups may represent "captive audiences" in that programs can be conducted during work or school hours. The advantages of this approach include convenience for all participants and the ability to focus the material on the intended audience. Another method for educating the 
public involves passing labeling legislation which is often a costly, lengthy process of unknown effectiveness. 
Chapter 4

LEGAL ISSUES 


\section{CHAPTER 4 - LEGAL ISSUES}

This chapter discusses the legal framework in which household hazardous waste issues must

be addressed. It describes federal regulations and identifies the types of state regulations in existence. The issue of liability is discussed within the appropriate legislation in the context of what municipalities face.

\section{FEDERAL LEGISLATION}

There are two federal statutes that are somewhat connected to the household hazardous waste issue. These are The Resource Conservation and Recovery Act (RCRA), 42 U.S.C.A. $\$ \$ 6901$, et. seq., and the Comprehensive Environmental Response, Compensation and Liability Act, 42 U.S.C.A. $\$ \$ 9601$ et. seq., known as CERCLA, or "Superfund."

\section{RESOURCE CONSERVATION RECOVERY ACT}

The Resource Conservation Recovery Act (RCRA) was enacted in 1976. The scope of RCRA includes solid waste management of any kind. Solid waste is defined extensively in section 1004 of the statute; ultimately, almost every waste is subject to RCRA guidelines.

Subtitle C of RCRA, as amended in 1984 and 1986, sets forth regulation of all hazardous wastes. Implicitly, since HHW is solid waste, and by definition is hazardous, one would conclude that HHW is governed by RCRA Subtitle C. However, legislative history indicates that Congress did not want the EPA to treat HHW as Subtitle C waste.

Therefore, the EPA issued a regulation at the advent of their RCRA program. The regulatory provision governing the HHW exclusion is codified in 40 CFR (Code of Federal Regulations) Section 261.4(b)(1) which states that the term "hazardous waste" shall not be construed to include HHW. HHW is a solid waste, but is not a hazardous waste, and for that 
.reason is exempt from Subtitle C of RCRA. The exclusion extends to the waste stream itself rather than the individual or entity that generates the waste.

Until recently, this exclusion was lost if household wastes were mixed with other hazardous wastes from any source, including conditionally exempt small quantity generators (CESQG). (40 CFR § 261.2(a)(2)(ii)). This burdened municipalities that accept CESQG waste at their collections, as they would be faced with the substantially increased costs associated with full Subtitle $\mathrm{C}$ requirements. The only way to reduce these burdens would be to manage CESQG waste and HHW waste separately (i.e., not mix them in the same container). Even this approach has significant downsides due to the duality in paperwork, space requirements, packaging, shipping and disposal efforts. The result is that many collection programs refuse to accept CESQG waste. This represents an unnecessary barrier to communities and companies who are trying to practice environmentally sound management of CESQG waste.

A clarification recently released from the EPA states that, "Programs and facilities receiving and mixing CESQG waste and HHW are subject to requirements imposed by States through the States' municipal or industrial waste permit, license, or registration programs, but are not subject to the full hazardous waste Subtitle $\mathrm{C}$ regulations, even if the mixed CESQG and HHW were to exhibit a characteristic of hazardous waste. The collection facility does not become the generator of the mixture merely by mixing CESQG waste with non-hazardous waste, and regardless of the quantity of the mixture of the waste, is not subject to the 40 CFR Part 262 generator regulations." (OSWER 1992)

\section{COMPREHENSIVE ENVIRONMENTAL RESPONSE, COMPENSATION \& LIABILITY ACT}

The Comprehensive Environmental Response, Compensation and Liability Act (CERCLA), commonly known as the "Superfund" Act, was enacted in 1980 and revised in 1986 by the Superfund Amendment and Reauthorization Act (SARA). CERCLA has been described, 
particularly by corporate officers and corporate lawyers, as the most aggressive, harsh, unconstitutional and unfair environmental statute ever enacted by Congress. (Dougherty 1987) This criticism stems from the provisions of Section 107 which enables the EPA to recover their costs of cleaning up a Superfund site (a place identified by the EPA as contaminated) from absolutely everyone ever associated with transporting hazardous substances to the site. The statute imposes "joint and several liability". "Joint and several" means that even if there are many parties identified as being associated with transporting hazardous substances to the site, any one may be held liable for the cost of cleanup in entirety, despite that party's individual contribution.

Moreover, once the EPA has resolved its liability with a responsible party, whether through a court judgement or settlement agreement, they still have the statutory right to seek further damages from that party if they find the initial remedy at the site was not effective. The party is still liable regardless of the amount of time that has passed since the initial cleanup.

\section{STATE LEGISLATION}

Many states have developed a series of laws, rules, regulations for guidelines, studies and funding mechanisms which are too numerous and diverse to mention here. Some of the laws are comprehensive while others only establish a state program. Guidelines or regulations govern how a local sponsor administers a program and, in some cases, require that the state review a plan before the collection program is held. State matching grants have been a successful way of encouraging more collection days. States continue to play an active role in this issue in many parts of the country.

One type of state legislation that was reviewed was hazardous household product labeling legislation. There are two federal statutes that address labeling of hazardous products: the Federal Hazardous Substances Act, 15 U.S.C. $\S 1261$ et seq, and the Federal Insecticide, 
Fungicide, Rodenticide Act, 7 U.S.C. $\$ \S 136$ et seq. The Federal Hazardous Substances Act (FHSA) governs the labeling of all consumer products containing hazardous substances. The FHSA establishes minimum standards for labeling information based on the toxicity of the chemicals within a product: it is only concerned with acute or immediate effects. It does not require that the long term or chronic effects of a substance be taken into account when labeling requirements are developed. It also does not require ingredients to be listed or that environmentally sound disposal information for unused products be included. The Federal Insecticide, Fungicide and Rodenticide Act (FIFRA) regulates the manufacture, use and disposal of agricultural and household pesticides. All pesticides must be registered by FIFRA, and they must be classified for either general or restricted use. Pesticides can only become registered if properly labelled: the label is required to carry a warning or cautionary statement to prevent injury to humans or the environment. (Findley 1988)

Regardless of the preference of federally mandated product labeling over shelf labeling by state respondents to the survey, pointed out in the previous chapter, state shelf labeling legislation is the only legislation being passed in recent years. Lobbyists have been unsuccessful in attracting attention at the federal level, so states have adopted their own legislation and programs. Industry is opposed to state-by-state labeling, although the paint and coating companies are the only ones to voluntarily develop labeling information. Despite this opposition, there is increasing interest by state governmental entities in legislation which alerts the consumer to the disposal dangers of HHW. This interest in not limited to the state level. Santa Monica, California is currently drafting a retail store shelf-labeling ordinance. (Purin 1992) A summary of state legislation follows. 
Iowa

Iowa was the first state to adopt Household Hazardous Material (HHM) legislation, doing so as part of the state's Groundwater Protection Act of 1987. (lowa 1987) Waste disposal and hazardous waste handling were identified as major threats to Iowa's groundwater. The state is responsible for developing, in cooperation with distributors, wholesalers, and retailer associations, a HHM list to be used by retailers.

In their legislation, lowa requires every retailer who sells products identified as a HHM to obtain a $\$ 25$ annual permit. These monies provide funding for program administration and Toxic Waste Cleanup Days. They presently have 12,805 permitted retailers, resulting in over $\$ 300,000$ annual income for their program.

In order to ensure that retailers are obtaining the necessary permits, the Department of Natural Resources (DNR) works with the revenue agency who sells the permits. They have established a computer program to monitor sales tax permits and HHM permits by Standard Industrial Classification (SIC) code. Retailers in SIC codes that have a high probability of selling HHMs and do not have a permit are sent a letter alerting them to the law and requiring them to either obtain a permit or sign an affidavit that they sell no HHMs. Over the three years that this system has been in place, it has been very effective in identifying negligent retailers, according to the survey respondent.

In addition to paying a fee, retailers must also label shelves with information on concentrations of HHMs and place posters and brochures for public education in nearby locations. These educational materials are provided by the state and paid for by the permit fees.

Monitoring retail establishments for proper display of the HHM program materials without any field staff presented a challenge to the DNR. County sanitarians, environmental activists, students and other interested parties have assisted in this endeavor. Staff members check for 
compliance on their own as they shop, and the revenue and finance staff check when they routinely check permits, approximately twice annually. They are also utilizing local volunteers in communities selected to host Toxic Waste Cleanup Days.

The resistance by retailers to the extra permitting fee was somewhat mollified by the knowledge that the money is spent primarily on Toxic Cleanup Days. The greatest resistance came from retailers who sell only one or two HHMs primarily for the convenience of their customers. Many that did not make more than $\$ 25$ annually on those products have decided to phase them out of their inventory.

A survey conducted by an MIT graduate student evaluated the success of the labeling program in three areas in Des Moines. (Zielinski 1988) The results of the survey suggest that over $80 \%$ of consumers did not understand the purpose of the label, and therefore did not alter their purchase or disposal habits with regard to HHMs. This suggests that a shelf labeling program alone may be an inadequate solution to this problem.

\section{Vermont}

Vermont Law 10 VSA 6621 requires retailers to label shelves that display HHMs and provide information pamphlets, prepared and paid for by the state, describing the toxicity of the products and alternatives to their use. The list of targeted products was developed primarily from the Iowa law, but they are adding products as the "rules" are developed.

The program officially began on April 8, 1991, despite retailer opposition and concern about loss of sales. The cost of the program for the first year is $\$ 18,000$, not including a half time staff person, and there are no funds raised by the program. Enforcement was to begin nine months after the start-up date with non-compliance being a violation of the solid waste law with a fine of up to $\$ 10,000$. The enforcement methodology is currently being developed. At last count, 
approximately 60 percent of the retailers were complying with the law. The success of Vermont's labeling program has not yet been measured.

Minnesota

A comprehensive waste reduction and recycling law, passed on October 3,1989, states that the Minnesota Pollution Control Agency (MAPA) may adopt rules to identify household products that are, or that contain, a problem material and to develop a uniform label to be used by retailers on display areas for those products. (Minnesota 1989) The legislation was the result of a Governor's Select Committee on Recycling and the Environment (SCORE), a group of government officials, industry, business, labor, legislators, citizens and environmentalists. The committee's charge was to develop recommendations, by consensus, for dealing with the state's growing waste problem. However, the legislation did not provide funding or staff for this program.

The program was a small part of a major bill relating to waste, and the shelf labeling provision drew little attention. The lack of funding given to the program indicates that it was not a high priority. Due to the lack of funding, and the fact that the program was not mandated by the legislation, there is not a shelf labeling program planned. During a recent legislative session, a bill to fund the program and to place a tax on certain hazardous constituents of household hazardous products was considered but not passed.

New Hampshire

House Bill 776-FN in New Hampshire states "the reduction of household hazardous materials as the top priority of the state for hazardous waste and toxic material management". The bill is modeled partially after the Iowa legislation in that it requires retailers to obtain a permit to sell certain defined products. The permitting fee is $\$ 50$, paid annually. 
The New Hampshire bill deals with distributors of pesticides separately. These distributors may obtain a single permit for its authorized retailers. The fee increases from $\$ 50$ to $\$ 200$ if the distributor's gross retail sales are $\$ 3,000,000$ or more in the state. This fee increases an additional $\$ 200$ for $\$ 3,000,000$ increments in sales, with a maximum fee of $\$ 5,000$.

Also similar to Iowa, retailers must post signs where HHM are displayed for sale. The signs must list the products ingredients and identify their residues as hazardous waste. (This bill excludes products such as laundry detergents, chlorine bleach, personal care products, cosmetics and medication.) The New Hampshire bill also establishes a household hazardous waste disposal fee to be assessed on any purchase of a hazardous material in the state. The fee is $\$ .10$ per container or gallon; $\$ .05$ to be deposited into the hazardous waste management fund and $\$ .05$ to be retained by the retailer for administrative costs.

Maine

Legislative Document No. 1904 intended to amend Sec.4 of 38 MRSA $\$ 2164$ to levy a 25c per container fee on HHMs, to be paid by wholesalers and distributors, for the purpose of funding the statewide collection program. A payment stamp was to be affixed to each product. The fee was changed to a $1 \%$ surcharge, but the bill was killed in their Taxation Committee. The bill also required educational pamphlets, produced and paid for by the state, to be distributed by retailers to their customers. A redraft of the legislation is planned for introduction into the next legislative session.

\section{POTENTIAL LIABILITIES}

In addition to the deliberation of liability associated with CERCLA, another liability issue can arise: that associated with performing some type of collection function. Following that discussion are two court decisions involving liability for cleaning up a municipal landfill Superfund site. 


\section{Collection}

In Policy Directive No. 9574.00-1 (Nov. 1, 1988), "Clarification of Issues Pertaining to Household Hazardous Waste Collection Programs", EPA provides further guidance. The guidance indicates that the exclusion under $261.4(\mathrm{~b})(1)$ is very broad in exempting HHW and facilities that handle, generate, treat, store or dispose HHW from regulation under Subtitle C of the hazardous waste program. Despite this, the EPA recommends that the materials be handled as RCRA Subtitle C hazardous waste. Under Subtitle C, documentation must accompany all hazardous waste from "cradle to grave." This includes using a licensed transporter and storage facility, as well as filing a manifest, the form that must accompany hazardous waste on its journey to the disposal site.

There are two ways in which collection program sponsors are potentially liable: for a transportation accident and for a problem at a collection site. Both of these situations present fairly manageable situations.

A spill resulting from a transportation accident is unlikely. The wastes would be containerized reducing the likelihood of soil or groundwater contamination. Although the EPA would seek payment from the sponsor of the program as well as the transporters, costs are likely to be low.

When municipalities transport their HHW to a RCRA hazardous waste management facility, there is joint liability by all parties depositing waste there and by the owners and operators of the facility. The owners and operators would be the first parties to pay as they have a legal obligation to do so by statute and their permits. The EPA requires them to provide financial assurances to cover problems and insurance to cover sudden and accidental releases. Collection program operators are at the bottom of the "potentially responsible party" chain where the liability has been estimated at a fraction of one percent. (i.e., for a $\$ 10$ million cleanup cost, the 
payment from a HHW collection program will be less than $\$ 1000$.) In addition, the EPA Office of Enforcement has a special policy for small (de minimus) contributors. Although the de minimus contributor is expected to pay its allocated percentage, EPA waives its legal rights to request further payment if the remediation, at a later date, is found to have been inadequate; the de minimus party does not have any further liability. (Dougherty 1987)

Superfund Sites

Finally, while looking at the potential legal liability for HHW management, municipalities must consider those associated with not establishing a HHW program. The EPA has said that municipalities are potentially liable at 25 percent of its 1,200 Superfund priority cleanup sites. (Moses 1992) CERCLA enforcement can be directed against landfill operators who are typically state and municipal governments. These suits are typically brought forth by third parties, not by the EPA. The EPA may bring municipalities in to the process if the municipal waste comprises the majority of the waste at the site.

The District Court of Connecticut, in B.F. Goodrich Co. v. Murtha (Civil Action No. H-8752, January 8, 1991), found that Connecticut cities are not automatically exempt from liability under CERCLA for disposing of municipal solid waste at two landfills, because:

- cities improperly relied upon the household waste exclusion in RCRA to argue that municipal solid waste is not hazardous waste under CERCLA,

- CERCLA does not specifically exempt household waste,

- and, the EPA said that municipal solid waste may contain hazardous substances.

The court found that cities may be liable even if they only arranged for disposal of the wastes.

This decision was upheld in a Federal Appeals Court in New York and while it has legal effect in only Connecticut, New York and Vermont, it is anticipated to exert a far reaching influence. The Appeals Court ruling is the highest judicial interpretation yet of the issue of 
municipal responsibility for cleanup costs. (Moses 1992) The case involved two landfills in Connecticut that will cost $\$ 47.9$ million to clean up. A group of companies that used the sites sued more than 20 municipalities, demanding that they pay a share of the cleanup costs. The court rejected the municipality's argument that they only used the landfills to dump household garbage, admittedly containing pollutants, ruling that the presence of any pollutant is enough to qualify under Superfund.

The allocation of costs is yet to be determined. The municipalities expect their costs to be low since their waste was the least hazardous. The companies, however, plan to argue that liability should be assigned based on the volume of wastes deposited in the landfill. Clearly, this would be a major blow to the municipalities. Efforts are being made in Congress to grant municipalities special status under Superfund.

On the west coast, in Transportation Leasing Co. v. California (No. CV 89-7368-WMB U.S., December 5, 1990), the U.S. District Court for the Central District of California also ruled that household waste is not automatically exempt from regulation under the Superfund law. The plaintiffs in the case are seeking contributions from the 29 defendant cities for cleanup costs at a Los Angeles County landfill.

The court found "without merit," the cities' argument that household waste is excluded from the definition of hazardous substances under CERCLA. The court said that even though RCRA contains an exclusion for household waste, it does not mean that exclusion is contained in CERCLA. The court added that if Congress had intended to exempt household waste under CERCLA, it could have done so expressly. The court noted that the "EPA itself has rejected the defendants' position that the 'household waste exemption' under RCRA is incorporated as a limitation on the definition of 'hazardous." It cited a 1988 EPA document stating that "Communities should recognize the potential liability under CERCLA [Superfund law] applies 
regardless of whether the household hazardous waste was picked up as part of a community's routine waste collection service and disposed of in a municipal landfill." The court found that HHW may qualify as a hazardous substance if it contains any of the substances listed in Table 302.4 of 40 CFR Part 302. (Table 302.4 lists approximately 60 pages of hazardous substances called "ETKM", or Every Toxic Known to Man.)

\section{CONCLUSION}

There are two main federal statutes which effect the handling of HHW. These are the Resource Conservation and Recovery Act (RCRA) which governs management of all types of solid waste, and the Comprehensive Response, Compensation and Liability Act (CERCLA or Superfund) which identifies contaminated sites and parties responsible for payment of cleanup.

RCRA specifically excludes household waste, including HHW, from regulation as a hazardous waste under 40 CFR 261.4(b)(1). This frees municipalities from having to comply with Subtitle $\mathrm{C}$ requirements governing transfer and disposal of hazardous waste. This exclusion has recently been clarified to include Conditionally Exempt Small Quantity Generator waste collected at cleanup programs. This clarification is good news for municipalities that wish to accommodate small businesses that have limited, low-cost disposal alternatives. (Including small businesses may also provide revenue sources for collection events.) Regardless of the exclusion, the EPA recommends that communities meet Subtitle $\mathrm{C}$ requirements for their HHW collection activities, presumably for their own protection.

CERCLA, or Superfund, is the statute wherein contaminated sites are identified, cleaned up and responsible parties sought to pay cleanup costs. Despite the exclusion of HHW as regulated waste in RCRA, recent court decisions on both coasts have found that municipalities can be named responsible parties, and as such, accountable for a portion of the cleanup cost. These suits 
against municipalities are typically brought by third parties being held responsible, not by the EPA.

Municipalities may also be found liable for accidents that occur while their waste is being transported or occur at the collection facility. Both of these potential liabilities are improbable and fines are expected to be manageable.

Many states have introduced shelf-labeling legislation as a form of education, and in some cases, as a way to generate revenue for the overall program. Iowa was the first to introduce such legislation in 1987 , and reports success with their program which mandates both a registration fee for retailers selling household hazardous materials and the display of educational information. (Davey 1991) This aggressive approach is aimed at altering consumer buying habits, or at a minimum, their disposal habits. Meanwhile, funds are raised to responsibly handle waste collection for communities. Effective management of legal liabilities requires policy for the removal of the hazardous component from the municipal waste stream to the extent possible, thereby eliminating the potentially devastating long-term liability of landfill cleanup under CERCLA. 
Chapter 5

POLICY RECOMMENDATIONS 


\section{CHAPTER 5 - POLICY RECOMMENDATIONS}

Hazardous materials are present in every community. Management of the risk posed by these materials involves important and unavoidable tasks for local planners. Although primarily intended to address the larger hazardous waste issue (Andrews 1987), the following statements can be applied specifically to HHW:

- Every hazard happens in some community. A hazard first affects the community in which it occurs, regardless of the state or federal programs instituted.

- Local government gets the calls. When a hazard occurs, it is the local government that the community turns to first for help. When local businesses face new federal solid waste disposal restrictions they turn to the local government first.

- Local governments handle hazardous materials themselves. Local governments use hazardous chemicals, identical to those used in households, in their own operations, generating the same types of wastes. (They are regulatees as well as regulators.)

Approximately 73 percent of persons involved in HHW management at the state level who responded to a recent survey (Davey 1992) felt that the HHW disposal problem was a very important aspect of the overall solid waste problem. Moreover, a majority of the respondents felt that the local government was the most appropriate entity to handle this problem (with the stipulation that the state provide at least a portion of the funding and some technical assistance.) All of these are compelling reasons, in the absence of a detailed, state mandated program, for local planners (specifically environmental planners) to establish an official position on this issue.

\section{GENERAL POLICY}

The planner should assess the existing conditions and the extent of the problem prior to establishing any type of management policy; What hazardous materials and disposal practices exist within the jurisdiction and what hazards are being posed. This is necessary in order to properly devise policy guidance. 
The planner must first establish a definition of HHW. This step will delineate the "bounds" for all subsequent policies. The existence of an established state definition should be checked and its use is strongly advised. Using a state definition will provide consistency later if programs are developed as part of a collaborative effort between two or more communities, or between a community and the state. A community always has the option to build on the state definition in order to create more stringent requirements and may be prompted to do so by public interest groups. Thus, the planner may find herself mediating between various interests early in the process.

The planner must determine the types, quantities and potentially harmful effects of $\mathrm{HHW}$ present in her community. With an established definition to guide her, the planner gathers empirical evidence from other studies or conducts her own if supporting resources are available. It would be prudent to make the decision of whether or not to include waste from small businesses at this point so that this waste is incorporated in the initial characterization of the problem. Given the fact that the EPA has granted an exclusion from regulation for small quantity generator waste, common sense dictates that this waste be included as a matter of policy. Businesses may be able to provide financial, technical, equipment, or volunteer assistance in return.

The planner makes decisions (or provides recommendations to decision-makers) on the need for a management program based on the results of her research, coupled with her firsthand knowledge of the community and its residents. If it is agreed that some type of waste management program is necessary, the planner may be the one primarily responsible for defining its general policy, design and implementation strategies. 


\section{MANAGEMENT POLICY}

Policy concerning management practices for household hazardous wastes can take two forms of compliance: voluntary or regulatory. Most communities have taken the voluntary approach through optional collection and education programs. Some states and communities have added a regulatory element by banning certain items from landfill disposal or by imposing additional costs on household hazardous products. Financial feasibility and public acceptance largely determine the policy approach taken. In general, a voluntary approach is believed to be more palatable to citizens. It is capable of fostering a sense of a community working together to solve or avoid a problem.

Regulations, on the other hand, are generated only after a lengthy process. All too frequently concessions are made by those promoting the regulation in order to get something passed that at least addresses a portion of the problem. A case in point is the lowa shelf labelling law discussed previously. By omitting certain HHMs (cosmetics, bleach, etc.) from regulation at the behest of a special interest group, an inconsistent message is delivered to the public. The legitimacy of both the regulation and its sponsors may be questioned.

These decisions are characteristic of those recommended by planners advising policy makers. The planner needs to state policy goals and spell out individual and department responsibilities clearly. This becomes even more critical when collaborating with other public or private entities.

\section{EDUCATION}

The goals of any educational policy should focus on raising awareness of the problems of HHW and emphasizing waste reduction as a sound solution to the problem. Goals of educational efforts should include teaching:

- what products can be hazardous and why,

- how to read product labels, 
- non-hazardous alternatives to toxic products,

- safe procedures for dealing with waste to reduce the risk, such as drying out latex paint, and

- how to safely store HHW.

Education programs are low-cost options that should be a part of every community policy. Costs, of course, will vary according to how ambitious the program is. Videos, slide shows, fact sheets and brochures are currently available from many states and public interest groups for little or no cost. It may be best to generate educational materials that focus on potential problems within the specific community rather than within a generic community.

Education programs should target specific groups. Education must be an active, outreach effort targeting specific populations such as school age children and municipal workers. Contests between schools and within schools not only compel the child to learn about the issue, but also the school staff and the parents. These "public interest" stories often reach the general public as well through the news media.

Purchasing agents must be directed to look for alternative products. The municipality itself must do its part thus setting the proper example. Persons buying supplies for municipal operations should be instructed to search for options to potentially hazardous products. Additionally, brief classes can be conducted during the workday for all municipal employees, not just those using the products in their work.

Educational goals should be prioritized. Reduction of the source of HHW should be the primary goal of education programs. This should be followed by reuse, recycling and disposal, in that order.

An example of a regulatory approach to education would be to implement some type of product labeling legislation. While some labeling programs perform the valuable function of raising funds for collection events, this approach is more appropriately implemented at the state 
or federal level. Executing and enforcing such a program is costly in both money and personnel; it is doubtful many communities have the resources necessary to perform an adequate job.

Education programs may eventually heighten community awareness of hazardous wastes to the point where citizens may require more of their local government. Citizens may express a need for additional information and advice, and perhaps even a collection option. An education program should be viewed as a way to reduce, but not eliminate, the need for more costly programs.

\section{COLLECTION}

Realizing that there will be a certain reliance on landfills for some time to come, reduction of the amount of HHW entering the landfill should be a policy focus. Collection of HHW is a much more costly and complicated option than education programs.

Focus on management of product-specific, larger volume wastes and eventually phase in other $H H W$. Product-specific options focus on either specific materials that can be managed in ways other than collection, such as paint, or on materials that are already being collected by someone else, such as lead-acid batteries, button batteries, and used motor oil. In either case, the community does not incur the costs of hazardous waste disposal. Special attention must be paid to the laws and regulations for these items so that the community does not accumulate these wastes and unwittingly acquire the burden and cost of disposal.

Product-specific options also succeed at diverting a large volume of waste, and perhaps the greater portion of the hazard, from entering the landfill. Starting with items for which there is an alternative to disposal allows the community to build some experience and expertise on the issue before phasing in wastes that prove more difficult to deal with. This option can be easily accomplished as motor oil and paints constitute the largest volume of HHW (Davey 1992) and can both be dealt with in ways other than costly, and wasteful, disposal. 
Review liabilities and insurance prior to collection events. If collection events become a reality, an insurance and liability review should be the first step in planning the event. The HHW issue is changing rapidly. The body of empirical data is growing and may result in new direction from the EPA or state environmental management agencies. If a community is planning a collection event, the state agency should be apprised of the plan to ensure it is in not in conflict with current direction. Additionally, insurance coverage should be reassessed to ensure it is adequate; additional insurance may need to be purchased for the event.

Collection activities must be made reasonably convenient to residents. The programs mentioned in Chapter 3 offer various levels of convenience. There is a fine line, however, between being "effectively" convenient and "too" convenient. Providing convenience to HHW collection sites is obviously intended to maximize the participation rate and hazardous waste collected, thus reducing the environmental and health threat posed by that waste. Unfortunately, many consumers see collection events only as an easy way to be rid of difficult to dispose of items. This removes the sense of waste "management." (Ridgely 1987) There is no magic formula for calculating the best level of convenience. The planner may need to rely on the experience of others, or on trial and error.

Collection activities must occur with reasonable consistency. Collection events should only be undertaken if there is commitment that they will continue in some regular fashion, even if only on an annual basis. Sporadic management of HHW may actually cause more harm than good as people become frustrated with the lack of consistency. The program, and those involved, may suffer a loss of legitimacy which will have further deleterious effects on future collection efforts. A study conducted after a single collection event actually found an increase in discarded HHW; the implication was that the widespread publicity created a heightened awareness of the danger of these products but did not provide an ongoing disposal method. (Ridgely 1987) 


\section{DISPOSAL}

Policy decisions must also be made concerning what available disposal options are acceptable to the community. Many residents may take an "out of sight, out of mind" attitude towards collection activities. As professionals, and mindful of the health and environmental concerns that initiated this action, planners must establish criteria for, or a ranking of, disposal alternatives.

Reuse and recycling options should be pursued over land disposal or incineration. For instance, if a community is not able to reuse or recycle all of the waste having this potential, they should state that reuse, followed by recycling, are their preferred options for "disposal" of some of the collected wastes. They are then bound to undertake the necessary steps in the program design to accomplish this policy objective.

The disposal options, both acceptable and prohibited should be spelled out in the policy statement. As another example, a community that has vehemently opposed the construction of a hazardous waste incinerator in their community, or even their state, would be hypocritical to send their collected waste to another state or country for incineration. This then, may appear on a list of prohibited disposal options. It is also necessary to prioritize acceptable options.

\section{COMMUNITY INVOLVEMENT}

Establish at the outset a volunteer, citizen involvement committee that includes members of businesses, civic leaders, public interest groups, and others with support from the local government. Volunteer participation is the key to an effective, low-cost program. Several case studies presented in Chapter 3 mentioned how essential a committed volunteer group is to the long term success of HHW programs. A strong volunteer group may also prove advantageous as a selling point if applying for program funding. 
HHW management programs offer many opportunities for participation by volunteers and activists which may be initiated and coordinated by the planner. Possible activities for volunteers are listed below, some of which were taken from The Minnesota Project. (Gelbman 1992)

- Volunteer bank: establish a local database of volunteers with various skills, and potential resources, to be tapped periodically for projects. This may include chemists, engineers, business persons, marketing experts, manual labor, teachers, university and business resources etc.

- Speakers Bureau: giving talks to local youth and adult groups. Topics include alternatives to using hazardous chemicals, changing buying habits, sage use of hazardous materials in the home, and simple disposal options for a few key materials like paint, batteries and used oil.

- Events: helping out at booths at local events such as county or church fairs, home shows, town and country shows etc.

- Local Outlets: contact local service stations, stores, and thrift shops to compile a list of local outlets for individual material. For example, contact each service station in town to find out if they are willing to take used oil from customers or the general public and if they are willing to have their name published on a list of used oil outlets.

- Collection Events: one-day collections in the past have used volunteers extensively. Future use of volunteers at these events will depend on the resolution of current debates on worker compensation and safety.

- Youth Projects: many projects could be developed for school age children, such as poster or logo contests, following the lead of "Just Say No to Drugs."

- Evaluate/Change Behavior: work with local groups like churches, school, home study groups, and service or environmental clubs to evaluate use of hazardous chemicals and to identify alternatives to chemicals.

- Home Inventories: help people to do inventories of the waste stored in homes and to identify alternatives. Simple disposal advice could be given for very common material, and referrals could be made to the solid waste office for information on less common materials. Another version of this idea is conducting a "Safe Home Tour."

- Test Markets Study: create a local "test market", similar to that created by marketing firms, to offer free use of alternative products to be reported on at the end of an established time frame.

- "Recipe Book": promote, on a local or regional level, a competition for recipes for non-hazardous alternatives to many products. Prizes could be donated by local 
merchants and the "Recipe Book" could be published and given away, or sold at a nominal fee to cover costs.

- Paint/Product Exchange: assist officials in organizing exchanges through a "paper exchange" wherein people list materials they want to give away and others contact them.

- Storm drain stenciling: a duck, fish or other logo, painted on storm drains along with a reminder not to dump wastes, may deter people from pouring wastes down that drain.

- Shelf-labelling: convince local merchants to voluntarily provide information on proper use and disposal at their store displays. Provide informational brochures and work to keep them in stock.

- Get involved: join or organize a committee to help formulate plans for local, state and federal action in managing hazardous wastes.

- Conduct Research: perform research on latest technologies to address the HHW problem, as well as on access to these technologies.

\section{PROGRAM EVALUATION}

The policy should describe the method, frequency and criteria for conducting program evaluations. Program evaluation "completes the loop" by critically measuring the level of success of the program. Far too often this crucial step is ignored, resulting in the perpetuation of ineffective programs.

Every step of the program needs to be evaluated. Is there a need to alter the definition of HHW? If there is new information on what is considered hazardous, or if the state has altered its definition, a change may be warranted.

The effectiveness of management programs must also be reviewed. A common gauge of program usefulness is to measure the number of households participating in collection events. If participation rates are lower than desired, contributing factors will be sought and new strategies tried. Another measure of success might be to track the sales of household hazardous products at random retailers for a certain period of time. This might reveal, for example, the effectiveness 
of education programs aimed at source reduction. It may be wise to include some type of time table enumerating how much time will be granted to achieve a certain measure of effectiveness.

Finally, program evaluation is often a necessary tool to justify continuation of a program. Being able to demonstrate a trend of progress may retain funding for a program in the municipal budget.

\section{CONCLUSION}

The general policies discussed assume that there are no state mandated programs. They can be summarized as follows:

1. Define $H H W$. Communities should consider using the state definition, if one exists, for consistency and to enhance the potential of collaboration with other communities.

2. Define scope of problem. This policy statement should clearly state the perceived problems and will include the types of waste generators that are to be included in any program.

The management policies fall into four categories: education, collection, disposal and community involvement.

1. Education. Educational efforts should always be included due to the relatively low cost. They should focus on source reduction, target specific groups, and prioritize the available methods of management. Material may be more effective if it discusses potential or existing problems at nearby, known locations. Purchasing agents for a community government should pursue alternative products.

2. Collection. Priority of collection activities should follow that presented in the educational material. The initial focus should be on the larger volume wastes (oil and paint) followed by other items with a non-disposal options. Collection activities must be relatively convenient and consistent.

3. Disposal. Both acceptable and prohibited alternatives of disposal should be clarified and prioritized. Reuse and recycling options should take precedence over disposal.

4. Community Involvement. The local government should develop and support an all volunteer, citizen group early in the planning process. 
Finally, policy evaluation, of both the general policies and all program policies is a necessary and often overlooked step. This policy will spell out the evaluation criteria for each aspect of the program. It will also detail the frequency of evaluations. Additionally, consequences of evaluation outcomes should be indicated to provide an agreed upon follow-up action once the evaluation is complete.

Planners can recognize variations in policy approaches that might be adopted at differing points along the pathway from the source of hazardous household materials to their final disposal. This can greatly increase the success of a long term community management program. A greater understanding of where the various policy approaches can be used most effectively can aid in achieving the long term objectives of household hazardous waste management. 


\section{APPENDIX}


HAZARDOUS HOUSEHOLD SUUSTANCES IIST ("*DRAET"**; 6/87)

Washington State Dept. Of ticology Solid llazardous Waste Proqram a Center for Environmental Manaqement, Tufts Unlversity 'DOXIC CNTECONY TNULE,

Key: $\quad \because$ E many separate compounds

= any member(s) of chemical family named

? = hazardous characteristic pcobable but not

verified or inconslstent with other listings

n.o.s. = not otherwise specified

CAIr:GONIE:S

I. Automotive, Boat, Equioment Maintenance

II. llome and llousehold maintenance

III. Paint Products

IV. Reoair and Remodelling

V llobby. Pet and Recreation Products

Parsonal Care Products

VI L pesticides and llerblcides

CATEGORY PRODUCT

CHFMICAL

Troxic

CASt CA'

CAUSTIC CARCIN IGIIT

CAs:

N-Hutyl Alcohol --sec Butanol. n-

PC.B's - -see Polvchlorinated Bishenyls*

lityl Alcohol --sce Butanol

Rubber Solvent --see Petroleuin Naolitha

mintidyl --see ninuat

Trinolyohosnhate --see sodium Trinolyoliosibliate

Isonronyl Alcolinl - -see I somromanol

Varmana - siee Dichlorvos

Carbolic Acid --see l"lacnol

Aminonia --see Amunium liviroxide

Melihvl Alculiol -see Methanol

ritiyl Alcohol --see fithanol

nictiylene Giycol

tithylene filucol

IIIII) (Fisli) or

IIdialation

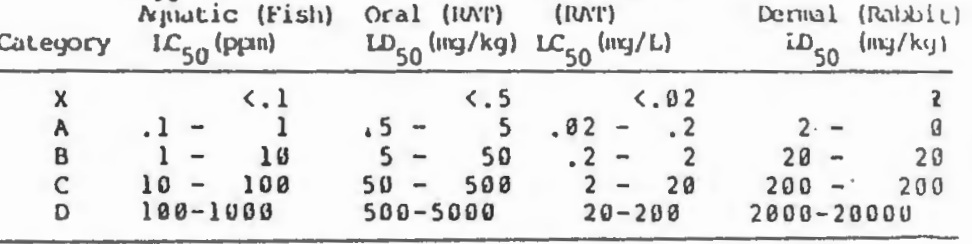

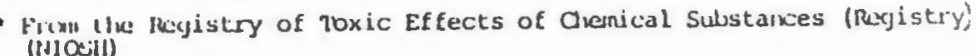

\section{Ant if reeze}

Antifreeze/Coolant

Auto Degreasers

Automotive Rublsing Conmounds

Automotive Rubbing Compounds

Batteries

let rachinroethylene

Cvcloliexallo

kerosene

Sulfuric Acis

licad

Bcake Fluid

Carbucetor Cleaners

Carpuretor cleaners

Carburetor Cleaners

Carburetor Cleaners

Convertible Ton Dressing

Convertible rop Dressing

Deqreasers

leavy Metal Contaminants*

cresol

Ethylene Dichloricle

rotassium llydroxide

soclium Chromate

stodidard Solvent

Petroleum Nanlitha*

Trichloroethylene

Deqreasers

Fiberalass. Resin llardeners

Hethylene Chloride

Diaminodiethylamine $-2,2$

Hethyl ethyl Ketone pecoxide

\begin{tabular}{|c|c|c|c|c|}
\hline $\begin{array}{l}111-16-6 \\
1107-21-1\end{array}$ & $?$ & & \multirow[b]{2}{*}{33} & \multirow{2}{*}{31} \\
\hline $\begin{array}{l}107-21-1 \\
127-18-4\end{array}$ & $\begin{array}{l}8 \\
x\end{array}$ & & & \\
\hline $2411-93-0$ & & & & \\
\hline $800 n-20-6$ & $?$ & & & 1 \\
\hline $766,4-93-9$ & C & 1 & & \\
\hline $7439-92-1$ & $x$ & & 1 & \\
\hline & $?$ & & & \\
\hline $\begin{array}{r}1319-77-3 \\
107-06-2\end{array}$ & B & $?$ & & \\
\hline $\begin{array}{r}107-06-2 \\
1310-58-3\end{array}$ & D & & 1 & $I$ \\
\hline $7775-11-3$ & c & 1 & & \\
\hline $80152-41-3$ & $?$ & 1 & & 1 \\
\hline $8030-30-6$ & & & & 1 \\
\hline $79-01-6$ & c & & 23 & \\
\hline $75-09-2$ & c & 1 & & 1 \\
\hline
\end{tabular}


Flberglass, Resin flardeners Gasoline

Gasoline

Gasoline

Gasoline

Gasoline

Gasoline

Gasoline

asoline

Leaded Gasoline

ubricat Ing oi

Lubricating 01

lubrlcating 01

Motor Fuel Additive

Radiator Flushes. Acldlc

Radlator Flushes. Acldic

Radiator Flushes. Acldic

Radiator Flughes. Acidic

Radiator Fluthes. Acldic

Radiator Flushes. Acldic

Radiator Flushes. Aclde

Radiator Flushes. Acldic

Radiator Flushes. Acldic

Radiator Flushes. Acldic

Radiator Flushes. Alkaline

Radiator Elushes. Alkaline

Radiator Flushes. Alkaline

Radiator Flushes. Alkallne

Radiator Flushes. Alkalline

Radlator Flushes. Alkallne

Radiator Flushes. Alkaline

Rust Inhlbitor

Transmission fluld

Transmission Fluid

Undercoat Inqs

Undercoatinas

Undercoat ings

Undercoat ings

Undercoat ings

MIndshield Washer Eluld

windshleld washer Fluid

Al Cleaners

Bleach

Bleach

leaches

Cleaning solution. Fabcic

Cotfee Pot Cleaners

Coltee pot cleaners

Concrete cleaner

Concrete Cleaner

Deck and Patio Cleaners

Deqreasers

Deqreasers

Deqreasers

Deqreasers
Denteasers
Cyclohexanone

Tetraethyl lead

Ethylene Dichloride

$x y$ lene

Ethylene Dlbromide

Benzene

orqanlc Phosphorous cmnds"

Aminestamine derivatives

l.ead

Tricresyl Phosohate

Petroleum Distillates *

lleavy Metal Contaninants *

Butanol. Iso

Sodlum Bisulfite

Boric Acid

Oxallc Acid

IIydrochlorle Aclo

rotass lum Dichromate

Butanol, $n$ -

Petroleum Ether"

I sontodanol

Olefins *

Butanol. n-

Sodium Orthosllicate

Petroleum Ether"

Isoprooanol

Sodluin Dichromate

Potassium Dichronate

Sodlun Trinolynhosnhate

Olef ins *

Storium

stoldaru Solvent

Petroleum Distillates.

Phenollc Resi

lleavy Hetal Pinments.

Alkyd Resin

Aromat Ic llydrocarhons"

Alinhat ic llydrocarbons

Isopronanol

Hethano

Cresol

Oxallc Acid

Sodlum Ilyoochlorite

Sodium Perborate

Carbon Tetrachlorid

Sodium Perborate

Sodium Tríolyohogohate

Phosiohoric Acid

Isoprodanol

Phosnhoric Acld

Dichlorobenrene, para-

Chlorlnated solvents"

Dichlornbenzene ortho

Petroleum Dlstillates"
Mnthylene Chloride
CAS\# CAT

CAUSTIC CARCIN IGNIT

$\begin{array}{rl}108-94-1 & \text { D? } \\ 70-80-2 & \text { A } \\ 107-06-2 & \text { D } \\ 1338-28-7 & C \\ 186-93-4 & C \\ 71-43-2 & C \\ 188-88-3 & C\end{array}$

$78-38-0$

$78-83-1$

$7601-90-5$

$10043-35-3$

144-62-7

$7647-81-0$

$7778-58-9$

$71-36-3$

$8032-32-4$
$67-63-8$

$71-36-3$

$11-36-3$

$8032-32-4$

$67-63-B$

$16588-91-9$

$7778-50-9$

$7440-47-3$

$8652-41-3$

-

- n.m-

-- - - -

67-63-0

67-56-1

$1319-77-3$

$144-62-7$

$7681-52-9$

$56-23-5$

7664-38-2

67-63-0

$3664-38-2$

$106-46-7$

95-50-1

$75-09-2$
D?
A
D
C
C
C
C

1

1

1

D

D

$?$

D

$?$

$?$

$x$
$?$
$?$

(n)




\section{CRIEMTCAL}

Deodorizers

Deodor izers

Deodorizers

Deodorizers

Dishwasher Detergent

Disinfectant

Disinfectant

Disinfectants

Disinfectant

Drain Cleaner

Drain Cleaners

Drain Cleaners

Drain Cleaners

Drain Cleaners

Drain Cleaners

Drain Cleaners

Fire Extinnulshers

Flreplace Cleaners

Fireplace Cleaners

Fireolace Cleaners

Fireplace Cleaners

floor Cleaner

Floor Cleaners

Floor Cleaners and fiaxes

Floor Cleaners and Waxe

Floor Wax

floor lvaxes

Flourescent Lamn Ballast

Eurniture Polish

Furniture Polish

llousehold Cleaner

llousehold Cleaner

llousehold Dencensers

laundiry Product.5

Laundry Products

Mercury Batteries

Metal Polish

Metal Polishes

mothballs

Mothballs

Oven Cleaners

Oven Cleaners

Oven Cleaners

Oven cleaners

Polishes

Polishes

Pollshes

Propylene Dichloride

Refigerant

Ruq Cleaner

Hug Cleaners

Septic Tank Cleaners

Seotic Tank Cleaners

Seotic Tank. Cleaners

Septic Tank cleaners

Seotic Tank Cleaners
Paraformaldehyde

Dichlorobenzene, para-

Naphthalene

Sodium Bisulfate

Sodium Tripolyphosphate

Cresol

Sodium llypochlorite

Formal dehyde

inmonium llydroxide

Sulfuric Acid

Petroleum Distillates"

Dichlorobenzene, ortho-

$T$ richloroethane-1, l.

potassium Hydroxide

llydrochloric Acid

Sodium llydroxide

Carbon Tetrachloride

Nabhthalene

Kerosene

Ethanol

Ayaroxide

Diethylene Giycol

petroleum Distillates.

Ammonius liydroxide

Diethylene Glycol

Ehylene Glycol

Polvchlorinated Binhenvis.

Oil of Cedarwood

Nitrobenzene

Sodiuin Dodecylbenzenesul fonate

sodium Trinolyolionnhate

perchlornethylenn

let $r$ achloroethvlens

sodium Trimolynliosnliate

Hercuric Oxide

Oxalic Acid

Pliosnhoric Acid

Dichlorobenzene. mixed

Naishthalene

potassillin Hydroxide

Methulene Chloritle

gorilin luaroxide

Trichloroethulene-1.1.1

Isorionanol

Petroleum Distillates.

Ethanol

Pronylene Dichloride

Dichloro-diflouromet hane

Trichloroethane.1.1.2

Nanhthalene

Trichloroethane-1.1.1

Hethylene Chloride

Dichlorobenzene. mixed

Petroleum Distiilated

'richloroethylene
TOXIC

CAS\# CAT

CAUSTIC CARCIN IGNIT

30525-89-4 $106-46-7$

$91-29-3$

$7681-38-1$

$319-77-3$

$7681-52-9$

$58-00-8$

$1336-21-6$

$7664-93-9$

95-50-1

$71-55-6$

$1310-58-3$

$7647-01-0$

$318-73-2$

$56-23-5$

$91-20-3$
$8008-20-6$

$64-17-5$

$1336-21-6$

$111-46-6$

$1336-21-6$

$111-46-6$

$36-30-3$

- $-2-2-2$

$9 B-95-3$

$25155-30-6$

$127-18-4$

$127-18-4$

$144-62-7$

$7664-3 u-2$

$7664-34-2$

$25321-22-6$

$91-26-3$

79-01-6

$67-63-0$

$64-17-5$

$74-87-5$

$75-71-8$

79-00-5

91-28-3

$71-55-6$

75-09-2

25321-22-6

$79-01-6$ 
Shoe Care Products

shoe Products

Smoke Detector

Spot Removers

Spot Removers

Spot Removers

Spot Removers

Tollet Bowl Cleaner

Tollet Вowl Cleaner

Tollet Bowl cleaners

Tollet Bowl Cleaners

Tollet Bowl Cleaners

Window Cleaner

Sinoke detectors, Ionjzation

Brush Cleaners

Brush Cleaner

Brush Cleaners

Brush Cleaners

Palint Remover

Palnt Strinoers

Palnt Strlopers

Palnt Thinner

Palnt Thinners

Paint and Varnlsh Removers

Palntbrush Cleaner

Palnt 9

Shellac and Resin Thinners

Solvent Based Palnts

Solvent Based Paint

Solvent Based Paints

solvent Based Paints

Solvents

Solvent

Solvents

solvents

solvents

Solvents

Solvents

Stripoers

Strloners

Varnishes, Shellacs. Lacquers

Varnishes, Shellacs. Lacnuers

Varnishes, Shellacs, Lacquers

Varnishes, Shellacs. lacquers

varnishes. Shellacs, Lacquers

varnishes. Shellacs. Lacquers

hater Based Palnts

Water nased Palnts

Hater Based Palnts

Water Based Palnts

Hater Based Paints

Water Based Paints
Mitrobenzene

Trlehloroethane, 1,1,2

Mercury

Tr Ichlor oethane , 1,1,2

Ammonlum liydroxlde

Sodlum ilypochlorite

Perchloroethylene

Sodium sulfate

Soulum oxalate

Dichlorobenzene, para-

oxallc Acid

llydrochlorle Acid

Diethiylene Glycol

$111-46-6$
Trlsodium Phosphate (decaliydrate) $10361-89-4$

$-241$

Benzene

xylene

Kerosene

roluene

Butanol. Iso

Sodluin llydroxide

Percliloroethylene

Toluene

Dichlorobenzene, ortho-

Bis 12-chloroethyllether

Trisodium Phosnhate (decaliydrate)

Cadmlum Metal

Methyd I sobutyl Ketone

Mineral Snleits

Butanol. n-

Petroleuin Nanhtha*

Hethyl Ethyl Ketone

Petroleum Naphtha*

Turbent ine

Cresol

Petroleum Fither*

Xulene

I sonronanol

Hineral Snirits

Butanol, n-

Trichloroethane-1.1.1

Methylene Chloride

Acetone

Ethanol

Ethyl Acetate

Urethane Alkyds

Butyl ncetate. n-

ncetone

Ethyl Carbamate

Chroinlun

Butadiene

Cuncous $0 \times 1 d$.

Cuncolss oxide

stycene Monomer

Zinc Oxlde

Iron oxide
fit livirnorivenl
$98-95-3$

79-08-5

7439-97-6

$79-00-5$

$1336-21-6$

$7681-52-9$

$127-18-4$

-

$106-46-7$

$144-62=7$

$7647-81-8$

$71-43-2$

$1330-20-7$

$8008-20-6$

$108-00-3$

$78-03-1$

$310-73-2$

$127-10-4$

$95-50-1$

19361-89-4

$16361-89-1$
$7446-43-9$

$106-18-1$
$100-40-2$

$71-36-3$

$8030-3 y-6$

78-93-3

$8030-30-6$

$8 \forall 06-64-2$

$1319-77-3$

$032-32-4$

$1330-20-7$

67-63-8

$71-36-3$

$71-55-6$

$75-89-2$

$67-64-1$

64-17-5

$141-78-6$

$123-06-4$

$67-64-1$

51-79-6

$440-47-3$

196-99-6

$100-42-5$

$1314-13-2$

SEO $\mathrm{NO}-17-7$ 
Wood Preservat lve

Wood Preservative

Wood Preservatives

Wood Stains

Wood Stains

Wood Stains

Adhesives and Glues

Adhesives and Glues

Adhesives and Glues

Adhesives and Glues

Adheslves and Glues

Adhesives and Glues

Adhesives and Glues

Caulking Compounds

Caulking Compounds

Caulking Compounds

Caulking Comoounds

Caulking Compounds

Drywall Matls.. Tiles. Cements

Electrical Insulation

Elceproofini Haterlals

Eurnace Cement

Insulation

Joint Compounds. Dey

Roof Coatings

Roof Coatings

Roofinn Shinales

Sealants

Sealants

Stove fining

stove tining

Thermal Insulatian

White leation

White head Puter

White lead

Wood Putty

Acids

Acids

Aerosols

Nerosols

Aerosols

Aerosols

nerosols

Aerosols

Aerosols

Alcohols

Alcohols

Alcohols

Artigt's paint "Cobalt violet"

Boteled Gas

Doteled Gas

Chetled Gas

Chemist
Dyes
Chromium

Pentachlorophenol

Arsenic

Lead

Benzene

Methanol

Petroleum Spirits"

Isopropanol

Nethyl Ethyl Ketone

Toluol

Urea formaldehyde

Toluene

Hethylene Chloride

Phenol

Lead

Kerosene

xylene

Asbestos

Ashestos

Asbestos

Asbestos

Sodium Silicate

Ashestos

Urea Formaldehyde

ishestos

Glycol Ethers"

Petroleun Distillates"

Asbestos

Styrene Monomer

Polyester Resins

timxy Resins

Astuestos

Borax

Asbestos

Asbestos

lead

Toluene

Acer.ic Acid

Tannic Acjd

Petcoleum Distillates

lleavy Hetal Based Pirments.

Toluene

Butane

Pronane

Ketones*

Chlorinated Hydrocarbons

Butanol. iso

Isooronanol

Benzyl Alcohol

Cobalt Arsenate

White cas"

Acetylene Gas

Heavy Hetal Based Piqments.

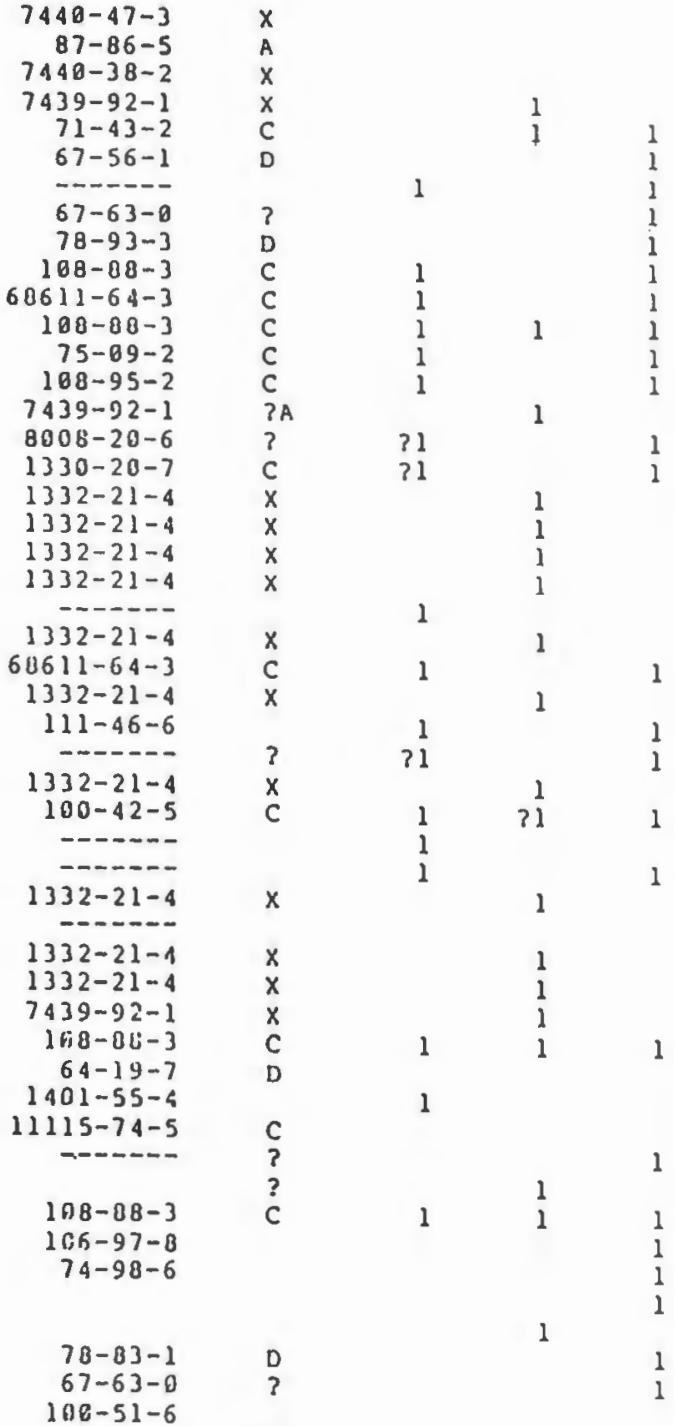

$74-98-6$

$74-86-2$ 
Glues and Cements

Glues and Cements

Glues and Cements

Glues and Cements

Clues and Cements

clues and cements

clues and cement

Glues and Cements

Glues and cements

liues and Cements

llobby Acid Solutions

Hobby Acids

llobby $A c$ ids

llobby Palnt 8 Varnish Removers

liobby Solvents

Carbaryl (sevin)

Dichlorophen

Chlordane

lleavy Metal Based Piaments *

Methyl Acetate

Methyl Methacrylate

Camohor

Botax

Petroleum Hanhtha

Petroleum nistillates *

Alcohols. n.o.s.

ineral splites

inexane

Fithylene Glycol

nenzene

Hethyl Acetate

Ainmonium Ilydroxide

Forinaluehyole

Sulfurlc Acid

phenol

Nitric Acid

Carbon Tetrachlorlde

Isoamyl Alcolool

Methanol
lineral

llolshy Solvents and Thinners

llobby solvents and Thinners

llobby solvents and ThInners

llobby solvents and Thinners

llobby Solvents and Thinners

llobby Solvents and Thlnners

llobby solvents and jhinners

liobby solvents and Thinners

llobby Solvents and Thinners

llobby Solvents and Thinners

llobby solvents and Thinners

Hobby Solvents and thinners

llobby Solvents and Thinners

llobby Solvents and Thinners

lloliby solvents and Thinners

llobby solvents and Thinners

llobby solvents and Thinners

colvents and Thinners

tobby solvents and Thinners

Hobby solvents and Thinners

llobby soly

lobby Waxes

Inks

Inks

Inks

Inks

Inks

Inks

Intis

Paint and Varnish Removers

Petroleum Dist 111 ates *

CAT

63-25-2

$57-74-9$

$79-28-9$

$80-62-6$

$76-22-2$

$8030-3 \theta-6$

$64-17-5$

$114-54+3$

$67-6,4-1$

107-.21-1

$71-43-2$
$79-210-9$

$1336-2.1-6$

$50-01)-0$

$7664-93-9$

$108-35-2$

$7697-37-2$

$56_{1}-23-5$

$23-51-3$

$67-56-1$

Petroleum Hanhtha

Carton nisulfide

Cellosolve

Tetrachloroethylene

chlorotoluene, ortho

Trichloroethylene

Ethylene Glycol

Carbon Tetrachloride

Metliyl Cellosolve

Cellosolve Acetate

Butyl Acetate, n-

Ethyl Acetate

Cartion Disulf lue

Nitrobenzene

Hethyl Chloroform

Lithot ine

Carbon qetrachloride

f.thylene Glycol

Acetlc Acid

lleavy Metal Based Plqments *

(a)

$8030-30-6$

75-15-0

$108-95-2$

$118-00-5$

$127-10-4$

$95-49-8$

$79-01-6$

$107-21-1$

$56-23-5$

$09-84-4$

$111-15-9$

$123-86-4$

$141-70-6$

$75-15-0$

$98-95-3$

$71-55-6$

$56-23-5$

$107-21-1$

Chromic Acid

$115-74-5$

Aromatic liydrocarbons *

$115-74-5$

Diethylene Glycol

$111-46-6$
$664-93-9$

Sulfucic

$7664-93-9$
$100-95-2$

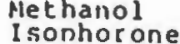

$67-56-1$
$70-59-1$ 
Paint and Varnish Removers Paint and Varnish Renovers Paint and Varnish Removers Paint and varnish Removers Paint and Varnlsh Removers Paint and Varnish Removers paint and Varnish Removers Paint and Varnish Removers Paint and Varnish Removers Paint and Varnish Removers Paint and Varnish Removers paint and Varnish Removers Paint and Varnish Removers paint and Varnish Removers Paint and Varnish Removers Paints

Paints and Photograny Chemicals Photogranhy chemicals Photodranhy Chemicals Photonranhy Chemicals Photoqraohy Chemicals Photodranliy Chemicals Photorranhy Chemicals Photorrantiy Chemicals photogranliy chemicals Photogranhy Chemicals Photodranhy Chemicals Photoqraohy Chemicals Photoquanly Chemicals Photoqranhy Chemicals photonraphy Chemicals Photogranhy Chenicals photor rany chemical Photograhy Chemicals photograny chemicnis Photograny cheinicals Photography chenicals Photography Chemicals Photoqraphy Chemicals Photography Chemicals Photoqraphy Chemicals photoqraohy Chemicals Pliotoquaphy Cliemicals Photography Chemicals Photoqraphy Chemicals Photoqraphy Chemicals Solvents and ihinners Solvents and Thlnners Solvents and Thinuers Solvents and Thinners Solvents and Thinners Solvents and rhinners solvents and Thinners Solvents and Thinners Solvents and Thinners solvents and Thinners Solvents and Thinners
Solvents and Thinners xylene

Isoamyl Alcohol

Toluene

Cyclohexanone

Methylene Chloride

Cresol

Methyl Isobutyl Ketone

Butanol. iso

vinyl Toluene

Acetone

Benzene

ilothyl Styrone. aloha

stycene lionome 6

Hetliyl Etliyl Ketone

Alkall. Concentcateri.

lleavy Hetal Based pinments

Potassium Perinannanate

rotassium Oxalate

potassium Dichromate

Plat inuin Chloride

potassium Clicome Alum

ncetic Acid

Potassium Cranide

Catechin

Braniull Hitrate

Ferricyanide

lertiary nutylamine sorane

llydrochloric heid

Sulfuric Acid

Iodine

Sorlitun Thiosulfate

Oxalic Acid

Sodiun llyuochlorite

Potassium chlocochromate

Sodiuin llydroxide

Diatlinooliynol llyarochlorile Sodium Dichiromate

llydroxylainine Sulfate

Sodiun Carbonate

phenyleneriamine, para-

Selenium Oxide

Formal dehyde

Ammonium liydroxide

Hercuric Chloride

Pyrogallic Acid

Ethylene vichloride

Petroleum Ether.

Dioxalle

Perchloroethylene

Alcohols. n.o.s.*

e chloride

chloroform

Ketones "

lurpentine

Khenol
$1330-20-7$

$123-51-3$

$700-94-1$

$70-83-1$

$25013-15-4$

$67-64-1$

$71-43-2$

$20-83-9$

1 ho $-42-5$
$70-93-3$

SE:? NO-B-6

$7722-64-7$

$7778-5 u-9$

$111025-65-7$

$64-19-7$

$51-50-0$

(1)

$6478-76-9$

-

$7647-01-n$

$7664-93-9$

$7553-56-2$

$144-62-7$

$7601-52-9$

$1310-73-2$

$584-01-9$

$10584-01-9$

$106+6-60-1$

$106-50-3$

$446-48-4$

$50-0(1)-8$

$1336-21-6$

$7487-94-7$

$107-66-2$

$8032-32-4$

$123-91-1$

$127-18-4$

$64-17-5$

$67-66-3$

$8006-64-2$

$100-95-2$
$0000-20-6$ 
Solvents and Thinners Solvents and Thinners Solvents and Thlnners Solvents and Thlnners Solvents and Thinners Solvents and Thinners Solvents and Thlnners Varnishes and Lacquers Varnishes and Lacquer Varnishes and Lacquers

Haxes

Waxes

Haxes

Waxes

Hood Staing

Denture Cleaners

Hall Polish themover

Nall Pollsh Remover

Nail Pollsh Removers

Nall nollsh \& remover

Rubbing Alcohol

Rubbina Alcoho

Crawling Insect Klller (nowder)

llerblcides

llerbiciden

Pest lcides

Pest lcides

Pestlcldes 6 lierbicides

peqticldes and llerbicides
Petroleun Narhtha*

Dichlorobenzene, $m i x e d$

Isoamyl Acetate

Cutting oils

Diathylene Glycol

Cycluhexane

Aromat lc llydrocarbons *

Alcohols. n.o.s."

Aromat Ic llydrocarbons"

Petroleum Dist lllates"

nenzene

Etliner

Polychlorinated Binhenyls"

Acetone

Turvent ine

Alcohols. n.o.s."

Étianol

Sodium Perborate

Diityl Acetate. n-

f.thul Acetate

Benzene

Inonronanol

Hethanol

Mercury

Chlorlane

Dirusat

Paraciuat

Carbaryl (Sevin)

Diazinon

Dichlorvos (DIDP)

Arsenic
cNs\#

CA'T

CAUSHIC CARCIN IGNIT

$0030-3 x-6$ $25321-22-6$ 123-92-2

SEก พ $\mathrm{HO}-36-1$

$11-46-6$

$110-02-7$

$64-17-5$

64--17-

$71-43-2$

$336-36-3$

$67-64-1$

B1)6 6-6,4-2

$64-17-5$

64-17-5

$123-66-4$

$141-70-6$

$71-43-2$

$67-64-1$

$67-63-8$

67-56-1

$7439-97-6$

$57-71-9$

BS- $00-7$

$1910-42-5$

$63-25-2$

$333-41-5$

$62-73-7$

$7440-30-2$
?

$\stackrel{?}{\mathrm{C}}$

(

?

C.

D

?

D 


\section{WORKS CITED}

Andrews, Richard. 1987. "Local Planners and Hazardous Materials." Journal of the American Planning Association 53: 3-5.

B.F. Goodrich Company v. Murtha, et al., Civil Action No. H-87-52 (PCD). U.S. District Court for the District of Connecticut, 1991, U.S. Dist. Lexis 230, January 7, 1991.

Brown, T. 1987. "Household Hazardous Waste Constituents and Their Impact." In Summary of the Second National Conference on Household Hazardous Waste Management, edited by The Center for Environmental Management, 146-147. Medford, MA: Tufts University.

Bureau of National Affairs, Inc., ed. "Cities Not Exempt for Trash Sent to Landfills." Chemical Substances Control, no. 270 (24 January 1991).

Bureau of National Affairs, Inc., ed. "CERCLA - Municipal Solid Waste - Exclusion." Environmental Reporter, no. 12 (1 February 1991).

Carra, Joseph. 1987. "EPA Perspective on Household Hazardous Waste." In Summary of the Second National Conference on Household Hazardous Waste Management. edited by The Center for Environmental Management, 6-8. Medford, MA: Tufts University.

Catherwood, Mary and John Lamb. 1992. The Rural Decision Makers Guide to Hozardous Waste Management. (March) Minnesota: The Minnesota Project.

Clean Water Fund. "Home Safe Home Chart," Providence, RI.

Cline, Stephen. 1989. "Stencil the Town Fishy." Sierra Club Magazine (March/April): 24-25.

Comprehensive Environmental Response Compensation Liability Act, 42 U.S.C.A. $\$ \$ 9601$ et seq.

Conn, W. David. 1989. "Managing Household Hazardous Waste." Journal of the American Planning Association 58 (Spring): 192-203.

Davey, Martha Josten. 1991. Results to mailed questionnaire on household hazardous product labelling legislation.

Davey, Martha Josten. 1992. Results to mailed questionnaire on household hazardous waste practices. 
Dougherty, James. 1987. "Hazardous Household Waste Collection Program Liability." In Summary of the Second National Conference on Household Hazardous Waste Management. edited by The Center for Environmental Management, 6-8. Medford, MA: Tufts University.

Duxbury, Dana, ed. 1990. Household Hazardous Waste Management News II, no. 7 (December): 4-6.

Duxbury, Dana, ed. 1991. "The National Listing of HHW Collection Programs."

Ehrich, Bruce R., Peter M. Summers and LeAnn M. Weih. 1989. Household Hazardous Materials in Iowa. (January.)

Environmental Project Group. 1990. "Household Hazardous Waste Collection Drive Funding Questionnaire." Leadership Omaha. (June)

Federal Hazardous Substance Act, 15 U.S.C. $\$ \S 1261$ et seq.

Federal Insecticide Fungicide and Rodenticide Act, 7 U.S.C $§ § 136$ et seq.

Findley, Roger W. and Daniel A. Farber, eds. 1988. Environmental Law. West Publishing Co: St. Paul, Minnesota.

Florida. 1992. "Household Hazardous Waste Management Program." Second Year Report.

Gelbman, Liz and Lola Schoenrich. 1992. In The Rural Decision Makers Guide to Hazardous Waste Management. (March) Minnesota: The Minnesota Project.

Iowa. 1987. Household hazardous materials, environmental protection, 567-144.1 (455F) et seq. IAC.

Iowa. 1992. "Household Hazardous Materials Toxic Cleanup Days Program." Annual Report. (January.)

League of Conservation Voters. (No Date.) "Toxic Waste: The Cleanup begins at home."

Krogulski, Marilyn. 1992. Telephone interview with Marilyn Krogulski, Iowa Department of Natural Resources, on December 13, 1992.

Maine. 1991. 115th Legislature. Legislative Document No. 1904.

Maples, Allen. 1987. "Defining Household Hazardous Waste" In Summary of the Second National Conference on Household Hazardous Waste Management, edited by The Center for Environmental Management, 6-13. Medford, MA: Tufts University.

Moses, Jonathan M. 1992. "Municipal Liability Under Superfund Seen." The Wall Street Journal. (March 13): B-3. 
Minnesota. 1989. Minnesota Statutes, Chapter 115A.952.

New Hampshire. 1991. House Bill 776-FN.

Resource Conservation and Recovery Act, 42 U.S.C.A. $\S \S 6901$ et seq.

Ridgley, Susan. 1987. "Overview of Other Management Options" In Summary of the Second National Conference on Household Hazardous Waste Management, edited by The Center for Environmental Management, 6-13. Medford, MA: Tufts University.

Schwartz, Anne. 1987. "Poisons in Your Home: A Disposal Dilemma." Audubon 89 (May): 1316.

South Dakota. 1992. "Toxic Cleanup Day Report." (January.)

Transportation Leasing Co. v. California. No. CV-89-7368-WMB, U.S.. U.S. District Court for the Central District of California, 21 CWLR 697 (December 5, 1990.)

U.S. Bureau of the Census. 1992. Statistical Abstract of the United States: 1992 (112th edition.) Washington, D.C..

Vermont. 1991. Vermont Law (10 VSA 6621).

Zielinski, Randi. 1989. Reducing Hazards from Hazardous Household Products. MIT Masters Thesis. 